\title{
Review of some Frasnian ahermatypic coral localities from Germany and description of a new genus Spinaxon (Anthozoa, Rugosa, Upper Devonian)
}

\author{
DIETER WEYER
}

Invalidenstrasse 43,D-10115, Berlin, Germany; dieterweyer@t-online.de.

\begin{abstract}
One of the greatest gaps in the present worldwide knowledge of Rugosa history are the unstudied ahermatypic coral faunas of Frasnian (and Upper Givetian) times, though they exist in many places. Most occurrences in Germany are briefly reviewed (Variscan Rhenish, Harz, Thuringian and Franconian Mountains; Baltoscandian shelf deposits in deep boreholes on the Baltic Sea island of Rügen). Intensive collecting in Thuringia presented rich Upper Frasnian samples from two localities (former Geipel quarry in the town of Schleiz, Vogelsberg-quarry near the village Tegau), dominated by Metriophyllum Milne-Edwards \& Haime, 1850, Neaxon Kullmann, 1965, and the newly established genus Spinaxon (suborder Cyathaxoniina, family Petraiidae), with the monotypic type species Spinaxon potyi sp. nov. Cephalopod limestones yielded $>100$ specimens of this taxon; one specimen was found in the Montagne Noire (Frasnian Famennian boundary stratotype section Coumiac). The taxon descends from Neaxon Kullmann, 1965 or its nearest relative Petraia Münster, 1839; it is characterized by unique hypertrophic long trabicular spines on the margins of major septa within an aulos of circulotheca type.
\end{abstract}

KEYWORDS: Frasnian, Kellwasser, ahermatypic Rugosa, Thuringia, Montagne Noire

\section{Introduction}

The Palaeozoic superorder Rugosa passed through several crises before the final extinction at the Permian-Triassic boundary. The most important one, the global Upper Kellwasser Event at the Frasnian-Famennian boundary, led to the disappearance of all coral reefs; they reappeared during top-Famennian times (Strunian). For a long period, the coral world of the Famennian (both photic and aphotic zones) was a terra incognita - but this changed surprisingly after the monograph of Polish ahermatypic Famennian Rugosa (Różkowska, 1969), and with the discovery of similar faunas mainly in Germany and Morocco, and also in northern China (Liao \& Cai, 1987; Cai, 1988; Wu \& Liao, 1988; Guo 1990). Knowledge about Famennian shallow water Rugosa increased more slowly: especially through Sorauf (1992: unique first upper Famennian, though pre-Strunian Rugosa fauna from North America) and Berkowski (2002: first upper Famennian, also pre-Strunian survivors of Frasnian Phillipsastreidae in Poland). Unfortunately, up to now there still are no certain Rugosa occurrences from the basal Famennian (Lower, Middle, and Upper Palmatolepis triangularis Zones, perhaps also Lower Palmatolepis crepida Zone). The only one Rugosa, which I could collect from the Middle Palmatolepis triangularis Zone, together with Nephranops incisus (Roemer, 1866), was an undeterminable ampleximorph taxon from Rübeland in the German Harz Mts.

At present, the Upper Givetian and the Frasnian ahermatypic Rugosa are the main worldwide information gap (in contrast to the broad knowledge about shallow-water corals of the same time span). Thus, Sorauf \& Pedder (1986, p. 1267) could speculate about a possible late origin of the basinal coral faunas in the Famennian - in reality they existed since the Silurian (rare in Wenlock, more often in Ludlow beds), but the majority remained unstudied and often even uncollected. Nowadays, nearly everywhere there are too few coral palaeontologists; so we must confess that e.g. the outstanding older monograph of Počta (1902) dealing with sometimes richer ahermatypic Ludlowian-Eifelian Rugosa from the famous Barrande collections in Bohemia, is still unrevised and nobody can interpret the many species using current actual taxonomy.

There prevail only scattered descriptions of Frasnian ahermatypic Rugosa, mostly isolated taxa in older literature, which often are in strong need of morphological revisions. Some of them were on the level of its time, e.g. Nicholsoniella baschkirica Soshkina, 1952 from middle Frasnian of the Southern Ural Mts. (Soshkina $(1952,1960)$, partly revised in Weyer (2000)). Others as some upper Frasnian species from the Kuznezk Basin did not consider the currently necessary, more intensively investigated ontogenetic stages: Nicholsoniella conica Bul'vanker, 1958, Nicholsoniella tomiensis Bul'vanker 1958, Nalivkinella breviseptata Ivaniya, 1965. Several "revisions" of Metriophyllum Milne-Edwards \& Haime, 1850 (Smith, 1945; Holwill, 1964; Weyer, 1970 - accepted in Hill (1981), but criticised in Weyer (1991)) used incorrect "topotypes": there exist two different unrelated genera with metriophyllid carinae in the Lower Frasnian of Ferques (Boulonnais, NW France). A thorough monograph of the corals from the Independence Shale of Iowa was published by Stainbrook (1946). Hill \& Jell (1971, western Australian Canning Basin) includes a modern study of several ahermatypic taxa. The contribution of Chinese authors to describe these Frasnian corals should be reviewed in that country.

\section{Ahermatypic Frasnian Rugosa in Germany}

The preliminary and subjective review of these mostly unknown and rare faunas is based on the few published studies and on available materials of some personal or museum collections. Undetermined and old-fashioned records in faunal lists are only partially mentioned; nevertheless they indicate a far greater distribution of such generally neglected corals.

\subsection{Rhenish Mountains}

This outstanding German Devonian area contains many Frasnian ahermatypic Rugosa, which remain mostly unexplored up to present times. Of course, there exist several mere records of such corals or old-fashioned determination in faunal lists, e.g. Schmidt (1921, p. 268: Amplexus sp., from Belecke, Belecke Anticline), Schindler (1990, p. 35, fig. 8, also Feist \& Schindler 1994, p. 198, fig. 2, Schmidt quarry S of Bad Wildungen, Kellerwald region), Schindler (1990, p. 40, fig. 11, Benner quarry near Bicken, Dill Syncline). Real palaeontological descriptions are rare exceptions and have never been revised: Ludwig (18651866), or Paeckelmann (1922: Amplexus sp. aff. helminthoides Frech, 1885, Metriophyllum? irregulare n. sp.). My access to this region started at first in 1990 after the reunification of the two German states, but was mainly concerned with Famennian and Lower Carboniferous strata, without intensive collecting in Frasnian beds. Some most promising localities can be mentioned.

\section{Martenberg near Adorf (now Diemelsee), east Sauerland region}

A first monographic study of the Middle Givetian-Lower Famennian sequence at this famous locality, a remnant of an ancient iron ore open-pit mine, was by Holzapfel (1882, p. 259) aside from the dominating ammonoids, he mentioned in a faunal list "Petraja radiata Münster" and several "Cyathophyllumand Amplexus-like" coral fragments. Such old-fashioned determinations can not be interpreted in modern taxonomy without the original specimens, which surely are lost.

Rugosa seem to be less rare, but nobody ever had assembled systematic collections. An excursion in 1991, guided by Jürgen Kullmann and Dieter Korn, was allowed to take only a few loose pebbles (due to the protected status of the outcrop); they yielded four still undetermined Rugosa, approximately from the lower Frasnian level of beds 14-16 (Ziegler \& Sandberg, 1990, p. 26, fig. 3). Because of the difficult section situation (Kullmann \& Ziegler, 
1970; House \& Ziegler, 1977) - extremely condensed, some hiatus - very precisely bed by bed sampling would be necessary, controlled by accompanying ammonoids and conodonts, and with permission of the natural reservation authorities.

In 2003, Ralph Thomas Becker presented me one Rugosa from the middle Givetian of Martenberg: it is identical with Laccophyllum sp. of Weyer \& Zagora (1990, p. 26, fig. 2.1-6) from the same time level ("Stringocephalus Limestone" in Greifenstein facies, middle Polygnathus varcus Zone) of the classical Givetian locality Büchenberg $\mathrm{N}$ of Elbingerode in the Harz Mountains. This species is now determined as Hamarophyllum aff. belkai Berkowski, 2004 (Lower Emsian, Tafilalt, Morocco) - the age difference suggests caution over the true specific identity.

\section{Mount Beul near Eisborn, Sauerland region}

Small excavations near the top of the hill present the anoxic Upper Kellwasser Limestone, and below it $0.50 \mathrm{~m}$ cephalopod limestone (3 beds) - Lower Palmatolepis linguiformis Zone. The locality was mentioned in Wedekind (1913, p. 32, dealing with the ammonoid fauna), Becker (1993, p. 55), and Feist \& Schindler (1994, p. 200, with illustrations of the trilobite fauna). During an excursion in 1992 (with Raimund Feist and Dieter Korn), I collected ten Rugosa (nine Metriophyllum sp., one Neaxon sp.).

\section{Sessacker trenches near Oberscheld, Dill Syncline}

Frasnian trilobites and ammonoid faunas are well known since Richter \& Richter (1926, p. 279), Matern (1931), and the repeated famous Senckenbergian excavations. In 1995, Raimund Feist donated a Rugosa coral (collected in 1993) from trench no. VI, bed 21: a $12 \mathrm{~cm}$-thick limestone just below the Upper Kellwasser Limestone, dated as Lower Palmatolepis linguiformis Zone. The specimen is determined as Neaxon sp. A locality reference was given by Feist \& Schindler (1994, p. 199 fig. 3, also mentioning the presence of rugose corals). Surely, the extensive collections in the Senckenberg Museum at Frankfurt Main will reveal further unstudied coral materials

\section{Ancient iron ore mines around Oberscheld, Dill Syncline}

Ludwig (1865-1866) had described several corals from this region; all the outcrops are gone. The fossils were collected mainly by miners and now are found in many museum institutions: to name the Sandbergers collection in Wiesbaden, or the Rhenish Devonian collection of the former Prussian Geological Survey in Berlin (transferred in 1950 to the Humboldt University Berlin and stored at the Museum of Natural History). For a long period, the greater part of such faunas (with famous ammonoids) was accepted to be of lower Upper Devonian (Frasnian) age. Today, after radical stratigraphic changes and the fixation of new international time boundaries by means of stratotypes, the range of the iron ore horizon is Middle Givetian (Maenioceras terebratum Zone), Upper Givetian ("Pharciceras Zones", the classical German "toI $\alpha$ " of Wedekind 1913, 1918), and lower Frasnian (up to the Koenenites lamellosus Zone).

The majority of the coral taxa (Rugosa, Tabulata) will be of Upper Givetian age, but a precise revision is extremely difficult and demands ammonoid control, which sometimes might be possible with such old collections when bearing precise locality data (e.g. "mine Königszug, $60 \mathrm{~m}$ depth level, collection Lotz 1901-1902)", or "mine Königszug, Westfeld, collection Ahlburg"). These are Ludwig's coral taxa: Rugosa: Amplexus umbilicatus Ludwig, 1865; Anorygmaphyllum obtusum Ludwig, 1865 Hexorygmaphyllum radiatum Ludwig, 1866; Liocyathus loculatus Ludwig, 1866; Ptychocyathus excelsus Ludwig, 1866; Taeniocyathus trochiformis Ludwig, 1865. Tabulata: Liodendrocyathus tubaeformis Ludwig, 1866 [= Cladochonus]; Liocalamocyathus cancellatus Ludwig, 1866.

The taxonomy of all these species has never been revised. Only Schindewolf (1930; p. 124, fig. 15; 1931, p. 631-633; 1932 , p. 471, fig. 1) used for a certain time the genus name Ptychocyathus Ludwig, 1866 (as a senior synonym of Alleynia Počta, 1902), and intended to prepare a revision of Taeniocyathus Ludwig, 1866, which remained uncompleted and unpublished. Thus, in reality the coral faunas of the long-lasting iron horizon are unknown according to the standards of our time, and are difficult to re-describe, as all their localities have disappeared.
I know a few specimens in old Berlin collections, bearing the generic and specific names of Ludwig on their labels and suitable as topotypes.

Momentary, the publication of Ludwig (1865-1866) was declared to be invalid and put on the index of publications unavailable for zoological nomenclature (Opinion 946 ICZN, 1971). This was an unjustified and unacceptable act similar to the now formalized Devonian ammonoid case of Sobolew (1914a, 1914b) - both authors had proposed formulae instead of normal generic names. Therefore it would have been appropriate to suppress all the new genera of Ludwig, but not his species. By Opinion 2337 (2014), the International Commission of Zoological Nomenclature revised their earlier incorrect decision and re-established the validity of Sobolev's specific names: the same correction should be done for Ludwig (1865-1866).

\subsection{Harz, Mountains}

Not one ahermatypic Rugosa from the Frasnian cephalopod facies was available to me. Solitary corals were mentioned in faunal lists of the Adorf-Limestone (Frasnian) of the western Harz Mts. without any precise locality (Beushausen, 1900, p. 165, re-cited in Schriel, 1954, p. 95), famous type locality Kellwasser valley near Altenau ("Upper Palmatolepis rhenana Zone" above the Lower Kellwasser Event, Schindler, 1990, p. 50, fig. 19). These records could mean undeterminable fragments or unstudied materials.

An exceptional record of Metriophyllum sp. is one sample from the Winterberg quarry in the famous Iberg reef near Bad Grund (1990 donated by Eberhard Gischler, then Göttingen his conodont sample $70-$ Gischler, 1992, p. 140, fig. 40). It is a forereef limestone with reefal debris (big colony of the Tabulata coral Alveolites); this S-SE part of the quarry represents the Upper Frasnian (Upper Palmatolepis rhenana Zone) luff position of the atoll (Gischler, 1992, p. 26). There several limestone blocks contain a curious faunal mixture of destroyed reef corals (photic zone), benthic brachiopods of another community in somewhat deeper environment (probably with the ahermatypic Rugosa), and goniatites drifted perhaps as dead shells by prevailing SE tradewind.

\subsection{Western Thuringian Mountains (SE flank of Schwarzburg Anticline)}

In this part of the Thuringian Slate Mountains (with prevailing Frasnian cypridinic shale facies), really rare ahermatypic Rugosa were collected over a long period by local geologists and amateurs: near the town Steinach by Max Volk (1900-1969) in 1921-1938, near the town Saalfeld by Heinz Pfeiffer (1921-1994) in 1946-1955, Wilhelm Reuter (1925-1988) in 1970-1985, and Konrad Bartzsch in 1954-1965.

\section{Steinach area}

The somewhat richer materials around Steinach had been found in the period of active whetstone quarries, the last one of which was abandoned in 1966; nowadays all these once famous outcrops are gone (overgrown by vegetation). Weissermel (1939) described the collection; the greater part of his results is included in the publication of Volk (1939, pp. 265-266), which is indispensable for an understanding of the stratigraphical interpretation.

The detailed ages of the Upper Devonian coral faunas in Weissermel (1939) are doubtful for everybody not acquainted with the local stratigraphy. Weissermel used the abbreviations "tob, toc, toa" written on the labels of the Max Volk collection, and explained in Volk (1939, p. 151). These terms are the official mapping units, used for the Upper Devonian of Thuringia in the special geological maps 1:25 000 of the former Prussian Geological Survey (Preussische Geologische Landesanstalt) in Berlin, and introduced by Deubel (1929, pp. 69, 72, 76). Their modern terminology follows Bartzsch et al. (1999, pp. 167-172, 2008, p. 61):

tob $=$ c. $40-50 \mathrm{~m}$ Braunwacken and Braunschiefer $=$ Weinberg Member of Hirtenrangen Formation (middle-upper Frasnian).

toc $=\mathrm{c} \cdot 60-75 \mathrm{~m}$ Tonschiefer $($ Cypridinen-Schiefer $)=$ Lerchenberg Member of Hirtenrangen Formation (upper Frasnian) + Plattenbruch Member of Bohlen Formation (lower Famennian, Nehden substage, Cheiloceras genozone). Volk (1939) did not 
mention the Upper Kellwasser Event as dividing horizon between these two members, but he separated them as toI $\delta$ and toII according to his biozones using entomozoid ostracods (following and improving Matern (1929)).

toa $=$ großknotige Kalkknotenschiefer $=$ Mühlfelsen Member and Breternitz Member of Gleitsch Formation (upper Famennian, starting above the global Annulata Event).

Frasnian Rugosa in Weissermel (1939) are the following "taxa", cited according to his determinations (an *asterisk marks "taxa" said to occur in the lower Famennian, too; one specimen marked by "?" lacks any stratigraphical and locality data and could be either Frasnian or lower Famennian):

* p. 354, plate 14/15-17 Syringaxon (Alleynia) thuringiacus Weissermel, 1939

? p.355 Syringaxon (Barrandeophyllum) sp.

p. 359, plate 14/3 Zaphrentis sp. 1939

*. 360, plate 14/4-8 Zaphrentis curvatissima Weissermel,

* p. 361, plate 14/9-10 Metriophyllum volki Weissermel, 1939 1939.

p. 362, plate 14/13-14 Amplexus liliiformis Weissermel,

Note: Weissermel (1943, p. 11) corrected the determination of plate 14/8, being Zaphrentis curvatissima, not Metriophyllum volki. There (p. 6, pl. 1/3,4), he also identified - erroneously - a Frasnian Rugosa from a $19^{\text {th }}$ century locality Kirschkau NE of Schleiz (Planschwitz Beds) with his originally lower Famennian Lindstroemia? cornuhirci Weissermel, 1939.

All these taxa seem to be useless nomina dubia - due to the bad preservation (decalcified casts), insufficient morphological analysis and illustrations, no designation of holotypes. Besides, the Syringaxon (Alleynia) thuringiacus is a junior synonym of Neaxon pauciradiatus (Ludwig, 1865), a lower Famennian (Cheiloceras Genozone) species, found in the Plattenbruch Member (Bohlen Formation) of the Bohlen section near Saalfeld, well described by its author as Amplexus (based on material preserved mainly as casts.

Unfortunately, all the figured specimens, which in the cases of the four proposed new species of Weissermel (1939) could become possible lectotypes, are most probably lost. The loaned collection had been sent back to Max Volk by Waldemar Weissermel in about 1938-1940; then Max Volk had deposited the material in the Geological Institute of the University in Erlangen (as intended, Volk, 1939, p. 151). After the war, this institution more and more neglected its ancient collections - a deplorable actual situation in many German universities. Some small parts of the Max Volk collections were transferred to the whetstone museum (Schiefer-Museum) in his hometown Steinach, but there I could find only one badly preserved coral specimen labelled in the characteristic handwriting of Waldemar Weissermel (and not illustrated in his 1939 publication). In 2015, Dr. Michael Heinze (curator of the palaeontological collections, Geozentrum, Universität Erlangen) kindly informed me that they do not possess the Weissermel 1939 coral collection. Dr. Manfred Bayer (same institution) told me that some older collections were in about 2005 transferred to Nürnberg (Naturhistorische Gesellschaft); there, Dr. Gottfried Hofbauer, who once had made an inventory of that transaction, could only ascertain the absence of the Weissermel 1939 corals. Obviously, inadequate care and curatorship in Erlangen is responsible for the almost certain loss of the unique and nowadays unrecoverable Rugosa fauna.

Very few specimens from the Frasnian Max Volk collection remained in Berlin with Waldemar Weissermel. Mostly, at that time these were indeterminate corals (e.g. small size, calcareous preservation, with no chance for preparation of thin sections). After his death (1943), they were stored together with many other corals (mainly Devonian of Thuringia and the Bosporus) in a special cupboard as his left legacy. As responsible custodian I had to rearrange these faunas in 1966 according to the existing publications of Weissermel (1935-1943); this resulted in three revisions (Weyer, 1977, 1981, 1984b) of selected material.

Later preparation of three such specimens allowed a determination as Metriophyllum sp. (Fig. 1), of course not identical with the doubtful "Metriophyllum volki Weissermel, 1939 " of unknown generic position. The two specimens unfigured here are:

BGR.Berlin-X6604 - Mount Hirtenrangen NE Steinach (section 38 of Volk, 1939, p. 157), Upper Frasnian (Upper Palmatolepis rhenana Zone, Rabienella reichi Zone of entomozoid ostracods), lower Lerchenberg Member (Beds 76-84 = "Pferd", Volk, 1939, p. 185), collection Max Volk 1921-1938.

BGR.Berlin-X6603 - Mount Hofberg near village Hasenthal NE Steinach (section 51 of Volk, 1939, p. 158), middle Frasnian, Weinberg Member of Hirtenrangen Formation, collection Max Volk 1921-1938; determined by Weissermel (and mentioned by Volk, 1939, p. 220) as Zaphrentis sp. aff. curvatissima.

\section{Saalfeld area}

The scarce available unstudied materials comprise about 10 ahermatypic Rugosa from the famous Bohlen section NNW of Saalfeld-Obernitz (Pfeiffer, 1954, annexes 1, 2); Bartzsch \& Weyer, 2012, fig. 1). They were found in the Hirtenrangen Formation: both in the middle Frasnian Weinberg Member (Braunwacke, Braunschiefer), and in the Upper Frasnian Lerchenberg Member (Wetzschiefer). Nearly all represent a new small species of Metriophyllum Milne-Edwards \& Haime, 1850.
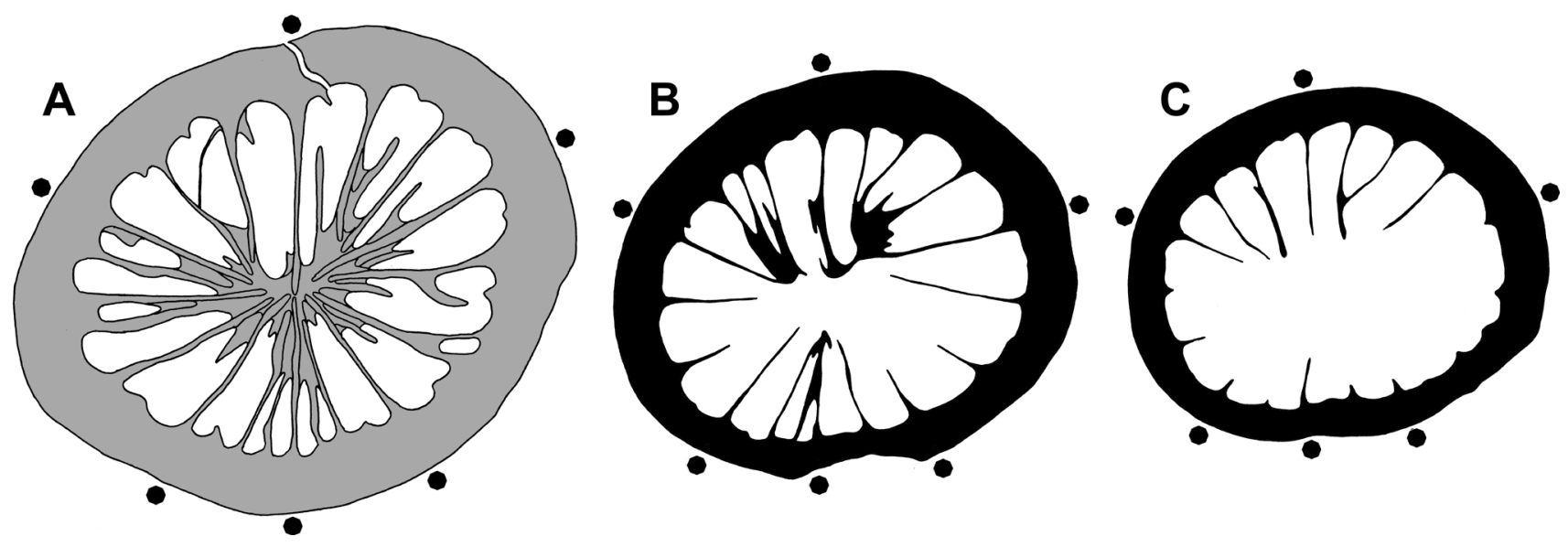

Figure 1. Metriophyllum sp., abandoned whetstone quarry at mount Lerchenberg, southern Steinach, Upper Frasnian (Upper Palmatolepis rhenana Zone), basal Lerchenberg Member (of Hirtenrangen Formation), bed 29 in section 20 of Volk (1939, pp. 175, 187), 3.80 m above the Lower Kellwasser Event (= bed 3+4 in Volk, 1939, p. 189); collection Max Volk 1921-1938, no. BGR,Berlin-X6602. A. cross section at calicular base, x10 (few subtabular interseptal lumina at the antiseptum and its catasepta); B, C. cross sections in the lower calice, x7 and x6 (with typical Metriophyllum features: long cardinal septum, well developed antiseptal triade, other minor septa extremely short, septal microstructure trabicular). See Table 1 for septal formulae. 


\subsection{Eastern Thuringian Mountains (NW flank of Berga Anticline)}

Middle?-Upper Frasnian cephalopod limestones of this region sometimes yield comparatively rich, though rarely collected and mainly unstudied ahermatypic Rugosa. Mostly, they can be found during the active period of quarries. The small solitary corals are enclosed in hard limestone, generally without a chance to isolate them; the best collecting method is to break the rock perpendicular to the bedding plane, to look for suitable cross sections, and to saw them out of the stone in an accurately oriented manner.

Two ancient quarries, abandoned long ago, were visited without measurements of the section: former Braunsberg quarry ESE of Tegau (with strong tectonical dislocations, active mainly in the $19^{\text {th }}$ century), and Kapfenberg quarry just $\mathrm{N}$ of Pahren, active 1897-1976, both mentioned in Müller (1956, p. 16). Loose limestone blocks of the Upper Frasnian (around the two Kellwasser Limestones, with locally famous homoctenite) yielded a few Rugosa, with one specimen of Spinaxon potyi from the Braunsberg quarry.

\section{Former Geipel quarry in Schleiz}

The first record was by Zimmermann (1915, p. 41 - small solitary corals, Cyathophyllum sp.). By chance, some of his few sampled Rugosa are preserved; they were deposited in the Devonian collections of the Thuringia province in the former Prussian Geological Survey, destroyed during the war in 1944. However, Otto Heinrich Schindewolf (member of the staff since 1929, later head of the collection department in this institution) had selected these specimens for his own studies, preserving them in his coral cupboards, where they survived. This also included some Upper Frasnian Rugosa from the immediately neighbouring former, now vanished Handmann quarry (mentioned in Müller, 1956, p. 11), obtained by Zimmermann in 1912 from the quarry owner Mr Handmann (a well known manufacturer in the town of Schleiz, just as Mr Geipel). About 1919, Schindewolf (1921, p. 172) visited the Geipel quarry and published a faunal list of Upper Frasnian ammonoids; the Rugosa also collected remained unpublished, but some first cross sections were prepared - they represent Metriophyllum sp. (Museum für Naturkunde, Berlin).

My own rich collection of 1995 (>100 Rugosa) comes from the $27 \mathrm{~cm}$-thick last limestone bed just below the Upper Kellwasser Event - high Upper Palmatolepis rhenana Zone and lower Palmatolepis linguiformis Zone. A preliminary note (Weyer et al., 2003, p. 74, fig. 2) gives a first impression of the unexpectedly diverse coral fauna, dominated by Metriophyllum, accompanied by Neaxon, Petraia (sensu Weyer, 2000), Metrionaxon, ampleximorph genera, and including also two specimens of the here described new taxon Spinaxon potyi.

\section{Former Kahlleite quarry $1 \mathrm{~km}$ SW of Rödersdorf (NNE of Schleiz)}

The locality offered an excellent Upper Devonian section (middle upper Frasnian - middle upper Tournaisian) during the quarrying period (Bartzsch et al., 1993, pp. 12-13, 2001, p. 104, 2008, figs 9-10; Gereke, 2004). This was finished in 2013; now the good outcrop condition has disappeared. In 19841985, I could collect eight loose limestone blocks containing 27 Rugosa corals; their age was always controlled by accompanying conodonts. They come from the cephalopod limestone sequence below the Lower Kellwasser Event, immediately below the "Ostracode Limestone" (= Usseln-Limestone of Gereke (2004), the starting point of his detailed measured section figure 5) Lower Palmatolepis rhenana Zone and Upper Palmatolepis rhenana Zone. Among the Rugosa fauna (with Neaxon and Metriophyllum), there are 2 specimens of Spinaxon potyi.

Vogelsberg quarry $1 \mathrm{~km}$ NNE of Göschitz (NNE of Schleiz)

For the moment, this outcrop (active since 1907 - Fig. 2) seems to be the best coral locality for Upper Frasnian ahermatypic Rugosa throughout the world. In certain beds of the cephalopod limestones, about 50 Rugosa will be found upon 1 goniatite Beloceras sagittarium (Sandberger \& Sandberger, 1851) and Gephuroceratidae. Perhaps, worldwide there might exist even better and richer coral occurrences, but up to now they remain uncollected and unstudied.

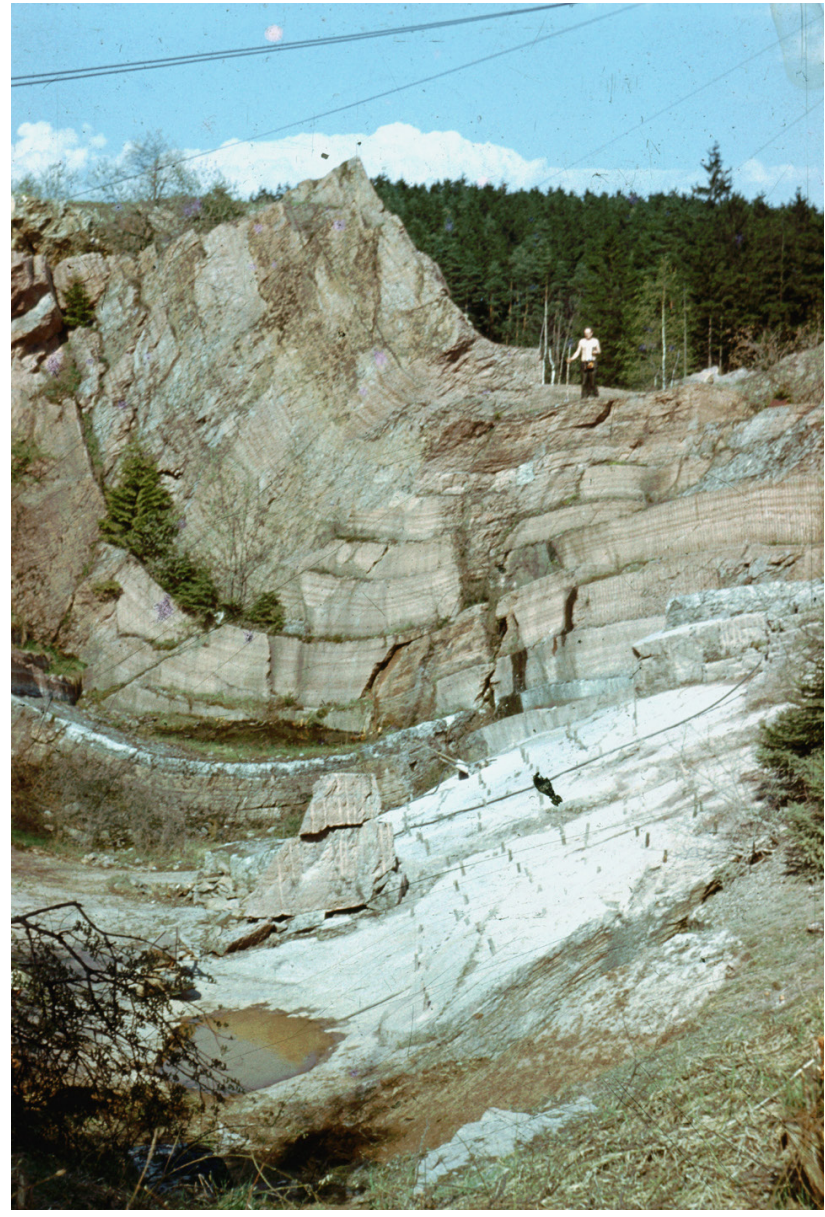

Figure 2. Vogelsberg quarry NNE of Göschitz before 1972, with remarkable fold in Frasnian-Famennian cephalopod limestones taken as marble blocks (destroyed in 1972-1973 by first use of dynamite to start a new technology for agglomerate marble, in relicts still preserved in Fig. 3).

In the years 1980-1983, also an excellent, still undescribed lower middle Famennian Rugosa fauna was collected at this locality (Weyer, 1984c, p. 19; 2004, p. 205) - from upper Nehdenian beds (Lower Palmatolepis marginifera Zone) with Paratornoceras lentiforme (Sandberger, 1857) and Acrimeroceras sp., and from the lower Hembergian (Upper Palmatolepis marginifera Zone) with Pseudoclymenia pseudogoniatites (Sandberger, 1853) and Cycloclymenia planorbiformis (Münster, 1832). Thecaxon horni Weyer, 2004, Kozlowskinia flos Różkowska, 1969, Laccophyllum thuringicum Weyer, 2004, and some new taxa occur there. These beds are now quarried away.

The Frasnian section (Fig. 3) offers two levels with rich Rugosa associations. The upper one (between the two Kellwasser Events) is dated as Upper Palmatolepis rhenana Zone and Lower Palmatolepis linguiformis Zone. The lower one (beds D-5, below the Lower Kellwasser Event) represents most probably the Lower Palmatolepis rhenana Zone. Palmatolepis rhenana rhenana Bischoff, 1956, the index fossil of the Upper Palmatolepis rhenana Zone, was observed in beds 7 and 9 .

The Rugosa fauna (about 400 specimens, coll. D. Weyer 19831984 ) is nearly the same as that from the Geipel quarry in Schleiz, and in even better preservation. Metriophyllum Milne-Edwards \& Haime, 1850 (in the sense of Weyer $(1991,1996)$ - according to a prepared revision by Rohart \& Weyer) is the characteristic genus. The new taxon Spinaxon potyi dominates with 109 specimens in the earlier beds below the Lower Kellwasser Event; the younger community in beds between the two Kellwasser Events yielded only two specimens.

\subsection{Baltic Sea island Rügen}

The Frasnian shallow water shelf sections of Rügen yield solitary Rugosa (genus Metriophyllum Milne-Edwards \& Haime, 1850 - Zagora \& Aehnelt, 2009, p. 161, fig. 1) in their deeper facies 
Figure 3. Upper Frasnian section of Vogelsberg quarry NNE of Göschitz (Bartzsch and Weyer in 1981-1984, 2014, unpublished), with the two nonanoxic Kellwasser Limestone horizons - outcrop situation of 1981-1984 (above and left, partly still preserved as nearly inaccessible steep quarry wall), and of 2014 in a deeper quarry level (first undisturbed complete Vogelsberg Formation with basal contact to the diabase vulcanites of the Görkwitz Formation) - source of rich ahermatypic Rugosa faunas between the two Kellwasser Events (Upper Palmatolepis rhenana Zone, Lower Palmatolepis linguiformis Zone), and below the Lower Kellwasser Event (Lower and Upper Palmatolepis rhenana Zones).

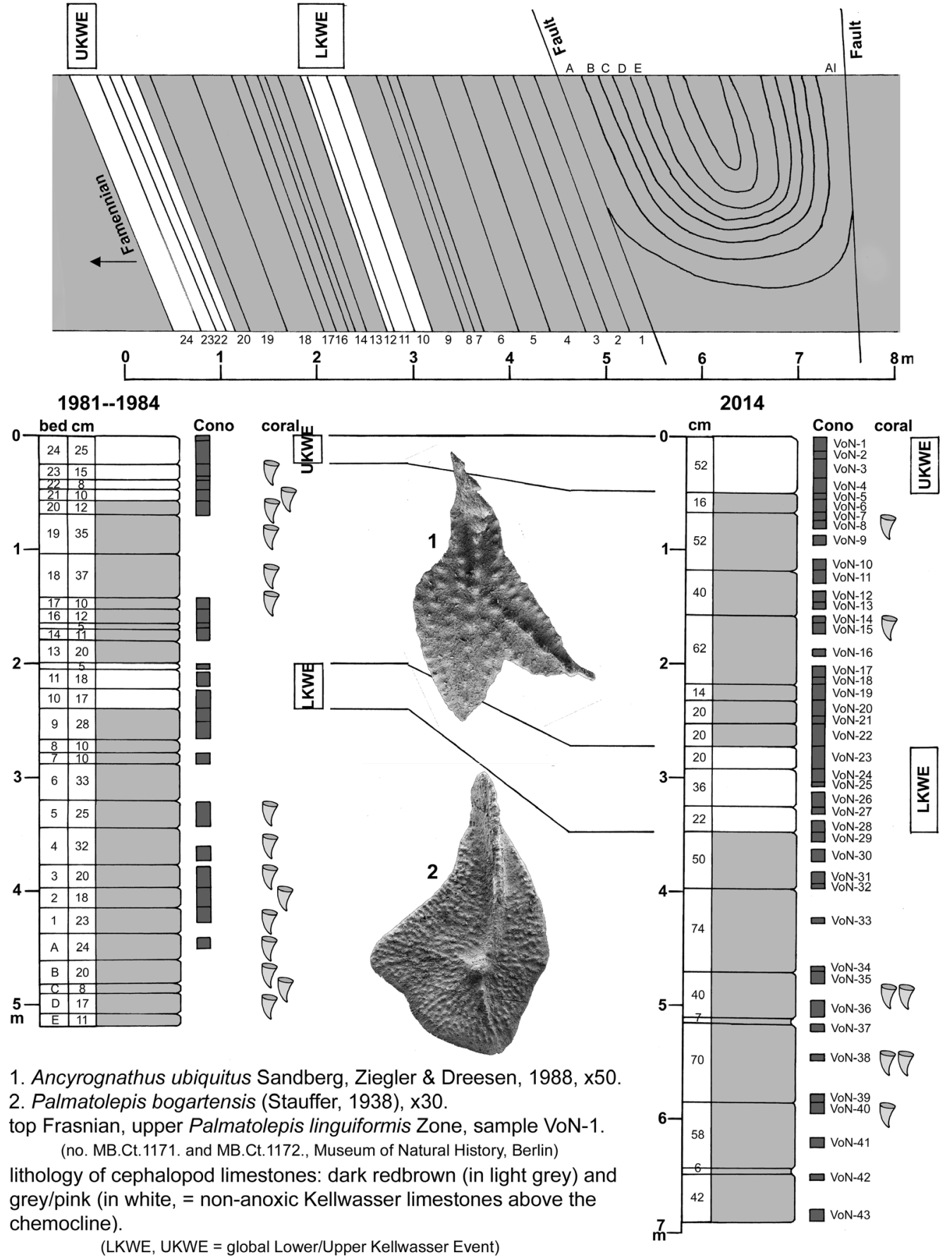

of Matagne type. I collected (1970-1974) all the materials from the available core of four deep boreholes. The coral faunas are stored in the Bundesanstalt für Geologie und Rohstoffe, Berlin Department (BGR.Berlin).

In the northwestern part of the island of Rügen, the Matagne facies occurs only in the Late Frasnian (Upper Palmatolepis rhenana Zone, lithostratigraphic unit 9a - Zagora \& Aehnelt, 2009):

Borehole Wiek 41969 (core 2385.0-2394.0 m; Zagora \& Aehnelt 2009: 178, section 6): Metriophyllum sp. $>20$ mostly fragmentary small solitary Rugosa.

Borehole Dranske 21970 (core 2625.2-2634.3 m; Zagora \& Aehnelt, 2009, p. 176, section 4): Metriophyllum sp. (Fig. 4 B1-3, sometimes settled by Auloporidae.

Borehole Neuenkirchen 11972 (core 3009.0 - 3019.0 m; Zagora \& Aehnelt, 2009, p. 101, section 9): Metriophyllum sp.

In the southeastern part of the island of Rügen, the Matagne facies starts already in the Early Frasnian (Palmatolepis punctata Zone, lithostratigraphic units 1a and 1'a - Zagora \& Aehnelt, 2009 , p. 185, section 13):
Borehole Binz 1 1973 (core 2872.5 - $2877.0 \mathrm{~m}=$ lithostratigraphic unit 1a; cores $3035.0-3044.0 \mathrm{~m}$ and $3058.0-$ $3075.1 \mathrm{~m}=$ lithostratigraphic unit 1'a): Metriophyllum sp. (Fig. 4 A1-6), Metrioplexus sp.

\section{Taxonomy}

The following abbreviations are used (especially in septal formulae): $\mathrm{n}=$ number of major septa, $\mathrm{N}=$ number of all (major and minor) septa, $\mathrm{D}=$ diameter, $\mathrm{CS}=$ transverse (cross) section, $\mathrm{LS}=$ longitudinal section, $\mathrm{TS}=$ thin section, $\mathrm{P}=$ peel, $\mathrm{R}=$ remaining piece of corallum. Six protosepta are marked in the transverse sections (cardinal septum at top); all illustrations are presented as seen from above into the calice.

Superorder Rugosa Milne-Edwards \& Haime, 1850

Order Stauriida Verrill, 1865

Suborder Cyathaxoniina Spasskiy, 1977

Remarks. This taxon is named Metriophyllina Spasskiy, 1965 in our classical Rugosa handbook (Hill, 1981, p. F186). Later revisions - not yet published (Rohart \& Weyer, in preparation), but first mentioned in Weyer (1991, p. 11, 1996, p. 


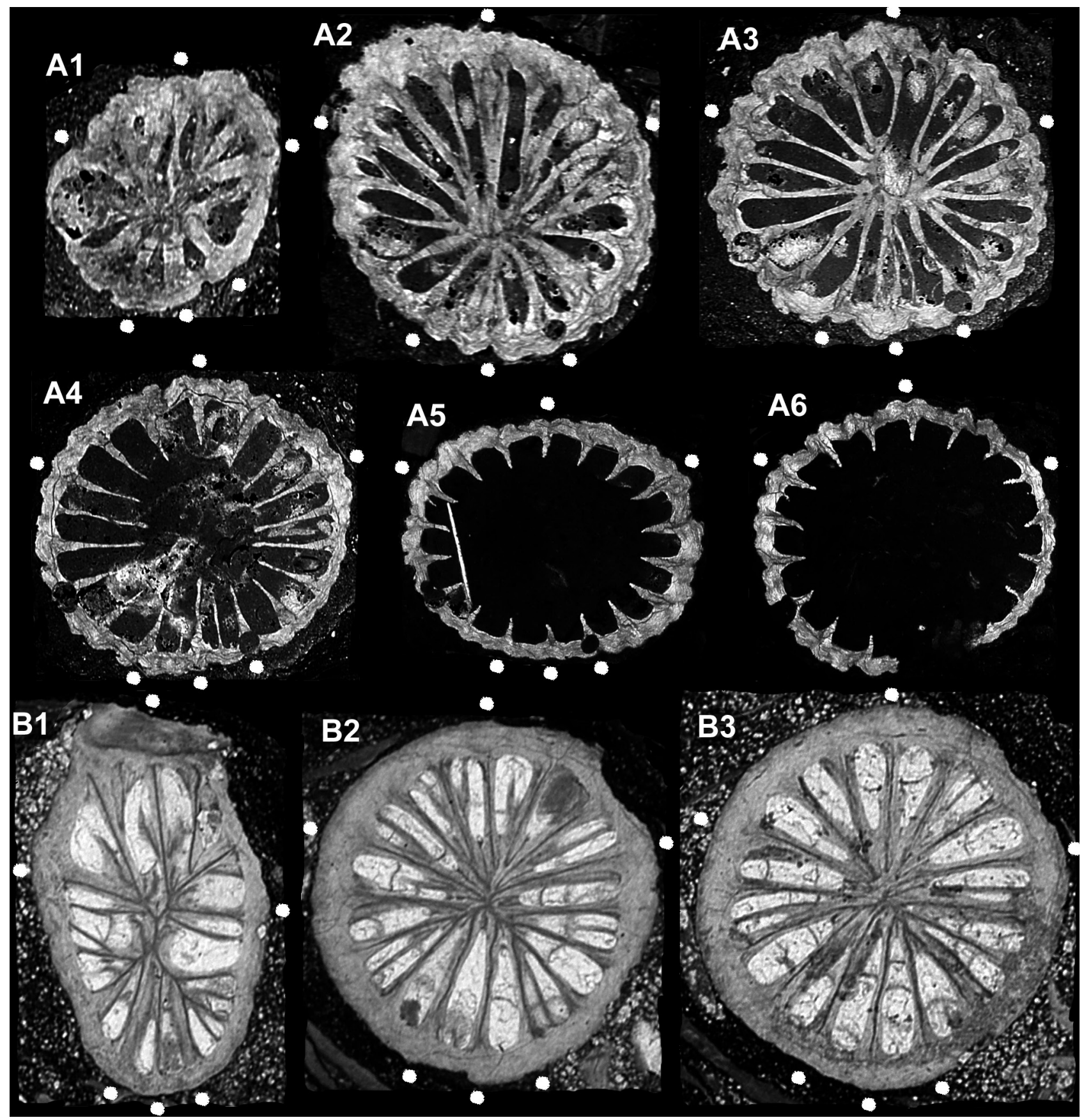

Figure 4. Frasnian Metriophyllid Rugosa from the Baltic Sea island of Rügen. A1-6. Metriophyllum sp. 1, lower Frasnian, borehole Binz 1 1973, depth 3036.2 m, coll. D. Weyer 1974 (BGR.Berlin X13224.), ontogenetic series of six calicular cross sections, x15 (A1), x12 (A2), x9 (A3), x8 (A4), and x6 (A56); - catasepta (excepting those of the antiseptal triad) in the highest calicular section A6 already reduced and incorporated into the stereoplasmatic thickened archaeotheca, visible only as external longitudinal septal furrows. B1-3. Metriophyllum? sp. 2, upper Frasnian, borehole Dranske 2 1970, depth 2625.7 m, coll. D. Weyer 1971 (BGR.Berlin X13223.); three subtabular cross sections, x15 (missing antiseptal minor septa triad does not correspond to the diagnosis of the genus Metriohyllum).

85) - resulted in drastic changes, because the real Metriophyllum Milne-Edwards \& Haime, 1850 is a member of the suborder Stereolasmatina Hill, 1981 (= Zaphrentoidina Schouppé \& Stacul, 1959) and its family Stereolasmatidae Fomichev, 1953, a junior synonym of Metriophyllidae Hill, 1939, which also will become a junior synonym of Lindstroemiidae Počta, 1902 (Lindstroemia Nicholson \& Thomson, 1876 is a senior synonym of Lopholasma Simpson, 1900). The main representatives of this suborder are the Cyathaxoniidae Milne-Edwards \& Haime, 1850, which include the Laccophyllinae Grabau, 1928 as immediate ancestor of the Cyathaxoniinae (lower FamennianLower Permian). The true, completely aseptal columella of Cyathaxonia Michelin, 1847 is nothing but the everted aulos of Laccophyllum Simpson, 1900 (Weyer, 1996, p. 85, 2001, p. 73). A trend (sensu Lang, 1923), seen in many Rugosa groups - trend towards contraclin contratingent catasepta and biform tabularium (often both features are closely connected) - occurs in the Cyathaxoniina, too: genera around Petraia Münster, 1839 and Neaxon Kullmann, 1965. Curiously, at first the contratingent structure was seen as the primitive (plesiomorph) septal plan (Schindewolf, 1931, 1942), but in fact the phylogeny was running in the opposite direction. Since a real cladistic classification (contratingent structure independently developed in various lineages) is not yet elaborated, such ancestral genera of the suborder are provisionally grouped as Petraiidae de Koninck, 1872 for the moment. Present knowledge is still too imperfect to allow better proposals for a natural classification; ahermatypic Rugosa seem to appear in Wenlock Ludlow times, but there is the outstanding misfit Protozaphrentis Yü, 1957 of presumed early Upper Ordovician age, with a well developed apomorphic contratingent septal arrangement. 
Family Petraiidae de Koninck, 1872

Remarks. We have no reliable subfamily subdivision of the included genera, classified by Hill (1981) as Neaxoninae Hill, 1981, Friedbergiinae Różkowska, 1969, Guerichiphyllinae Różkowska, 1969, and Amplexocariniinae Soshkina, 1941. In addition, the Bathybalvinae Weyer, 1991 had been proposed. The generally accepted revision of Petraia Münster, 1839 by Schindewolf (1931) is unacceptable (Weyer, 1980), as it did not rely on the original syntypes and defined the genus by a coral not present in the Münster collection, later renamed Muenstraia Weyer, 2001.

A special problem is due to the genera with dissepiments: Czarnockia Różkowska, 1969, Hillaxon Różkowska, 1969, Catactotoechus Hill, 1954, Nicholsoniella Soshkina, 1952, Guerichiphyllum Różkowska, 1969, Alborziphyllum Ashouri, Abbasi \& Khaksar, 2010. For the moment they are still united in a presumably artificial manner as the Guerichiphyllinae Różkowska, 1969. The pleonophorous structure (Rugosa with dissepiments, Dybowski, 1873) is often declared ex cathedra as a feature of family subfamily rank in taxonomy - such an oldfashioned procedure would be a typical "horizontal" classification not reflecting true phylogenetic lines. Monotypic taxa of the family group (subtribus - superfamily) are inadequate, therefore authors included dissepimental genera into mainly non-dissepimental subfamilies or vice versa (Hill, 1981: Catactotoechus Hill, 1954 in Neaxoninae; Berkowski, 2006: Vesiculolasma Berkowski, 2006 in Sutherlandiniinae; Weyer, 2001: Schindewolfia Weissermel, 1943 in Taralasmatinae).

Subfamily Petraiinae de Koninck, 1872

Synonym: Neaxoninae Hill, 1981.

Genera included. Neaxon Kullmann, 1965, Paliaxon Weyer, 1981, Neaxonella Weyer, 1978, Neosyringaxon Jia, 1977, Erfoudia Berkowski, 2008, Accurganaxon Li, 1979 (?synonym Marocaxon Berkowski, 2008), Petraia Münster, 1839, Spinaxon gen. nov., ?Nalivkinella Soshkina, 1939, ?Gorizdronia Różkowska, 1969.

\section{Genus Spinaxon gen. nov.}

\section{Type species. Spinaxon potyi sp. nov.} aulos.

Etymology. For the exaggerated trabicular septal spines in the

Diagnosis. Neaxon-like small long-conical corals with coarse monacanthine trabicular microstructure (multitrabicular only at the upper calicular margin).Cardinal septum as long as other major septa, also in calicular stages never shortened. Aulos (circulotheca) complete and mostly well developed, in mature stages often disappearing and reappearing during ampleximorph phases. Tabulae slightly domed. Radially arranged major septa outside the aulos at the calicular base with trabiculae fused to form platy septa, which bear inside the aulos extremely long thick trabicular spines often nearly reaching the centre, where they can bend upward nearer to a vertical growth direction. Their appearance within the circulotheca sometimes resembles an axial structure, but no real evert calicular boss can be observed. Minor septa are extremely short, sometimes obscure or apparently missing due to their spiny inner margin; no antiseptal triad.

Comparison. The ancestors of Spinaxon are the two closely related genera Neaxon (with complete circulotheca throughout growth) and Petraia (circulotheca incomplete in mature stages). The excessively elongated trabicular spines at the septal margin of major septa are the distinctive feature of the new genus - these spines enter the circulotheca (sensu Fedorowski, 2009) up to its centre. Such a structure never appears in Neaxon throughout its at least Lochkovian-top-Famennian lifespan, and also never in its descendant Petraia (for the moment known for certain only from Frasnian-Famennian times, but probably arising earlier).

Occurrence. At present, monotypic in the Upper Frasnian, Thuringia (Germany) and Montagne Noire (France). It is still unknown whether Spinaxon evolved only during the Frasnian or earlier in the Middle or even Lower Devonian.

\section{Spinaxon potyi sp. nov.}

Figs 5-6-7, Table 1, Pl. 1-4

2003 nov. gen. nov. sp. II; Weyer et al., 76, fig. 2E, F.

Etymology. Dedicated to Edouard - Eddy - Poty, on occasion of his $65^{\text {th }}$ birthday, and in recognition of his intensive studies of Upper Devonian - Lower Carboniferous Rugosa.

Holotype. specimen MB.K.7957 = 4 CS (1P, 3TS), 4 LS (TS) - Fig. 7 A1-4, P1. 1 G1-5.

Type locality. Vogelsberg quarry $1 \mathrm{~km}$ NNE of Göschitz (NNE of Schleiz).

Type horizon. Cephalopod limestone of the middle Vogelsberg Formation (bed A, Fig. 3, left section) - upper Frasnian, Lower

\begin{tabular}{|c|c|c|c|c|c|c|}
\hline specimen & figures & \multicolumn{2}{|c|}{$\begin{array}{l}\text { septal } \\
\text { formula }\end{array}$} & $\mathrm{n}$ & $\mathrm{N}$ & $\mathrm{D}(\mathrm{mm})$ \\
\hline \multirow{2}{*}{ MB.K.7949 } & \multirow{2}{*}{ Fig. 6 A1-A2 } & 3 & 3 & \multirow{2}{*}{16} & \multirow{2}{*}{24} & \multirow{2}{*}{3.8} \\
\hline & & 3 & 3 & & & \\
\hline \multirow{2}{*}{ MB.K.7949 } & \multirow{2}{*}{ Fig. 6 A3-A4 } & 2 & 3 & \multirow{2}{*}{15} & \multirow{2}{*}{22} & \multirow{2}{*}{$3.8-3.9$} \\
\hline & & 3 & 3 & & & \\
\hline \multirow{2}{*}{ MB.K.7953 } & \multirow{2}{*}{ Fig. 6 B1 } & 3 & 2 & \multirow{2}{*}{17} & \multirow{2}{*}{26} & \multirow{2}{*}{3.6} \\
\hline & & 4 & 4 & & & \\
\hline \multirow{2}{*}{ MB.K.7953 } & \multirow{2}{*}{ Fig. 6 B2-B3 } & 3 & 3 & \multirow{2}{*}{19} & \multirow{2}{*}{30} & \multirow{2}{*}{$4.3-4.5$} \\
\hline & & 4 & 5 & & & \\
\hline \multirow{2}{*}{ MB.K.7957 } & \multirow{2}{*}{ Fig. 7 A1 } & 3 & 3 & \multirow{2}{*}{16} & \multirow{2}{*}{24} & \multirow{2}{*}{3.5} \\
\hline & & 3 & 3 & & & \\
\hline \multirow{2}{*}{ MB.K.7957 } & \multirow{2}{*}{ Fig. 7 A2-A4 } & 3 & 3 & \multirow{2}{*}{18} & \multirow{2}{*}{28} & \\
\hline & & 4 & 4 & & & $3.9-5.2$ \\
\hline MD V 7056 & D1 241 & 2 & 2 & & & \\
\hline & 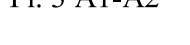 & 4 & 4 & & 27 & $3.2-5.0$ \\
\hline & & 3 & 2 & & & \\
\hline & Г1. 5 A3 & 4 & 5 & 10 & & \\
\hline $\operatorname{MD} V 7056$ & D1 2418 & 3 & 2 & & & \\
\hline סנון. & $1.584-0$ & 5 & 5 & 17 & 30 & $0.0-0.4$ \\
\hline & & 2 & 2 & & & \\
\hline IVDD.N. & 11.5 & 4 & 4 & 10 & 24 & 5.0 \\
\hline $9 \mathrm{DP} V 7060$ & $\mathrm{D} 1 \mathrm{C}^{\prime}$ & 2 & 2 & & & \\
\hline IVD.R. & 1.5 & 5 & 5 & 10 & 28 & 5.6 \\
\hline & & 2 & 2 & & & \\
\hline IVD.R./FO & F1.J & 5 & 5 & 10 & 20 & 4.3 \\
\hline$M$ & D1 $>$ & 4 & 3 & & & \\
\hline MID.A. $/ 901$ & 11. $502-104$ & 5 & 5 & 21 & 34 & $9.1-1-1$ \\
\hline & & 2 & 3 & & & \\
\hline МIB.К./9J4 & Pl. 4 Al & 3 & 3 & 15 & 22 & 2.7 \\
\hline & & 3 & 3 & & & \\
\hline IVID.N. $/ 954$ & P1. 4 AL-A3 & 3 & 3 & 10 & 24 & $3.8-4.4$ \\
\hline
\end{tabular}

Table 1. Septal formulae of selected specimens. 

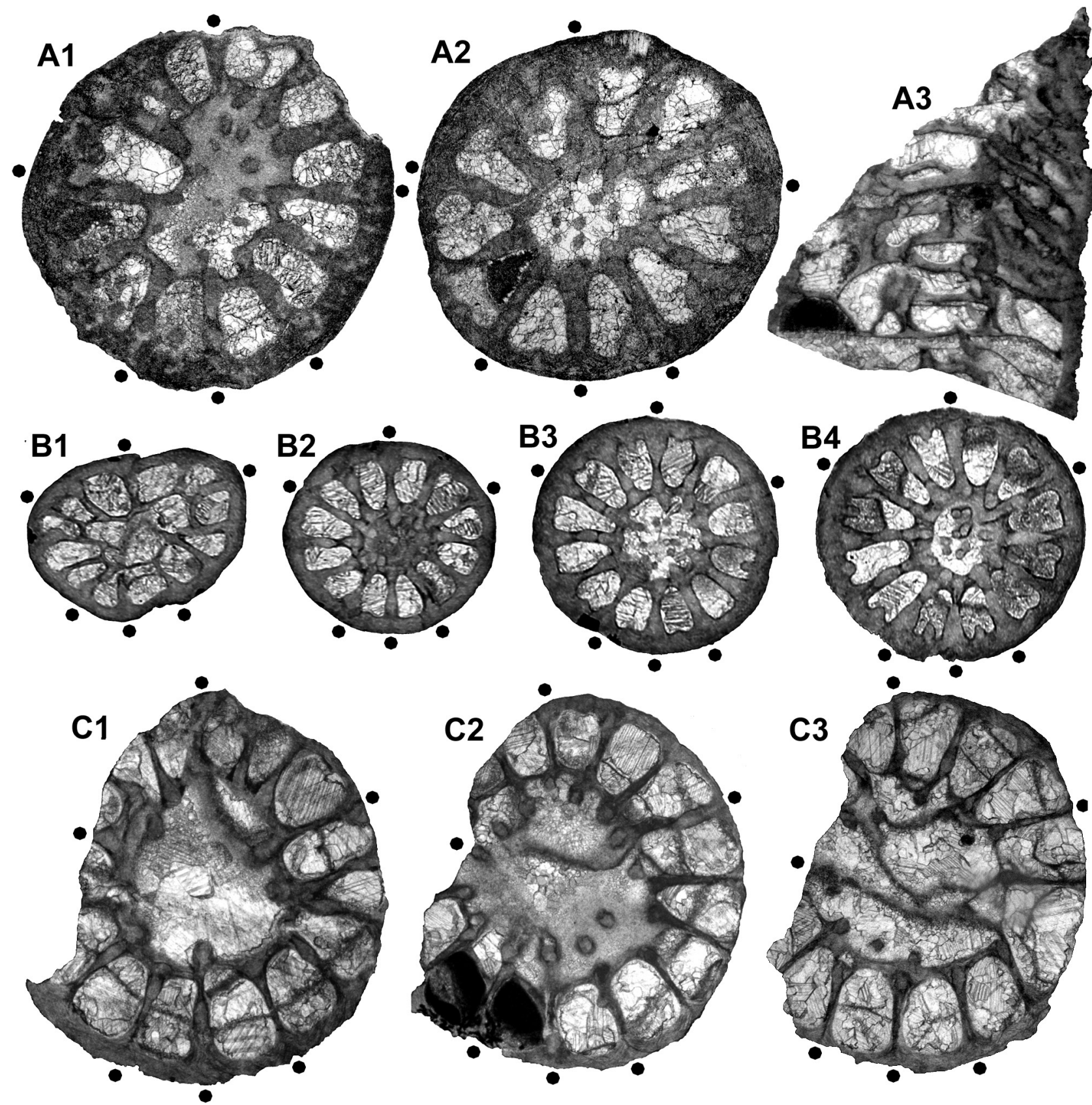

Figure 5. Spinaxon potyi sp. nov., paratypes, Thuringia. A1-3. MB.K.7949, former Geipel quarry in Schleiz, upper Vogelsberg Formation, bed 4A, Upper Frasnian, top of Upper Palmatolepis rhenana Zone, coll. D. Weyer 1995; A1, 2. subtabular cross sections, (nos 8, 5), x15, A3. median longitudinal section (no. 1), x12 (drawings see Fig. 6 A1-4). B1-4. MB.K.7950, former Geipel quarry in Schleiz, upper Vogelsberg Formation, bed 4B, Upper Frasnian, boundary of top Upper Palmatolepis rhenana Zone and Lower Palmatolepis linguiformis Zone, coll. D. Weyer 1995; subtabular cross sections, x10. C1-3. MB.K.7953, former Braunsberg quarry ESE Tegau, upper Vogelsberg Formation (loose block), Upper Frasnian, Lower-Upper Palmatolepis rhenana Zones, coll. D. Weyer 1966; subtabular cross sections (nos 5, 4, 3), x15 (C1) and x12 (C2, 3) (drawings see Fig. 6 B1-3).

Upper Palmatolepis rhenana Zone.

Material. 117 specimens from four localities in Germany (Thuringia) and from one locality in France (Montagne Noire). 241 thin sections ( 209 cross, 32 longitudinal) have been prepared from 40 specimens. 77 specimens were only cut and studied with at least one polished and $\mathrm{HCl}$-etched surface showing the long trabicular spines within the circulotheca. The collection is stored in the Museum of Natural History (Leibniz Institute) at the Humboldt University in Berlin (numbers MB.K.7949-7995), except four specimens from Vogelsberg quarry donated to the University of Liège (Collections de Paléontologie animale et humaine, numbers ULg.2015-05-22 1, 2, 3, 4). A geographic map of the Thuringian localities was given by Bartzsch et al. (1993, p. 6).

Vogelsberg quarry NNE of Göschitz - 111 specimens: The extremely rich collection was sampled from the older left Upper
Frasnian section in 1983-1984 (Fig. 3), now partly vanished and partly inaccessible at the steep WSW wall of the quarry. The great majority (109 Spinaxon) occurred below the Lower Kellwasser Event: bed 4 (2), bed 3 (16), bed 2 (43), bed 1 (1), bed A (10), Bed B (11), Bed C (1), Bed D (1), bed AI (23), loose pebble (1). Only 2 Spinaxon were found just below the Upper Kellwasser Event (undivided sample of beds 23-20, Fig. 1 - MB.K.7987.12). The illustrated specimens are: MB.K.7955 = 2CS (TS), 1LS (TS) - bed B - P1. 1 B1-3; MB.K.7956 = 11CS (5P, 6TS), 1R - bed A - P1. 1 A1-5, 3 A1-9; MB.K.7957 = 4CS (1P, 3TS), 4LS (TS) - bed A - Fig. 7 A1-4, P1. 1 G1-5, holotype; MB.K.7958 $=9 \mathrm{CS}(3 \mathrm{P}, 6 \mathrm{TS}), 2 \mathrm{LS}(\mathrm{TS})-$ bed $1-\mathrm{Pl} .2$ D1-3; MB.K.7959 $=6 \mathrm{CS}(4 \mathrm{P}, 2 \mathrm{TS}), 1 \mathrm{R}-$ bed $3-\mathrm{Pl} .1 \mathrm{f}, 3 \mathrm{~B} 1-3$; MB.K.7960 = 11CS (5P, 6TS), 2LS (1P, 1TS) - bed 2 - Fig. 6 C1-2, Pl. 4 D1-3; MB.K.7961 = 10CS (7P, 3TS), 2LS (TS) - bed B - Pl. 1 D1-2, 3 D1-4; MB.K.7962 = 3CS (2P, 1TS), 7LS (5P, 2TS) - bed $3-$ Pl. 1 E1-2, 3 C1-5; MB.K.7963 = 7CS (3P, 4TS), 2R - bed 2 - Fig. 

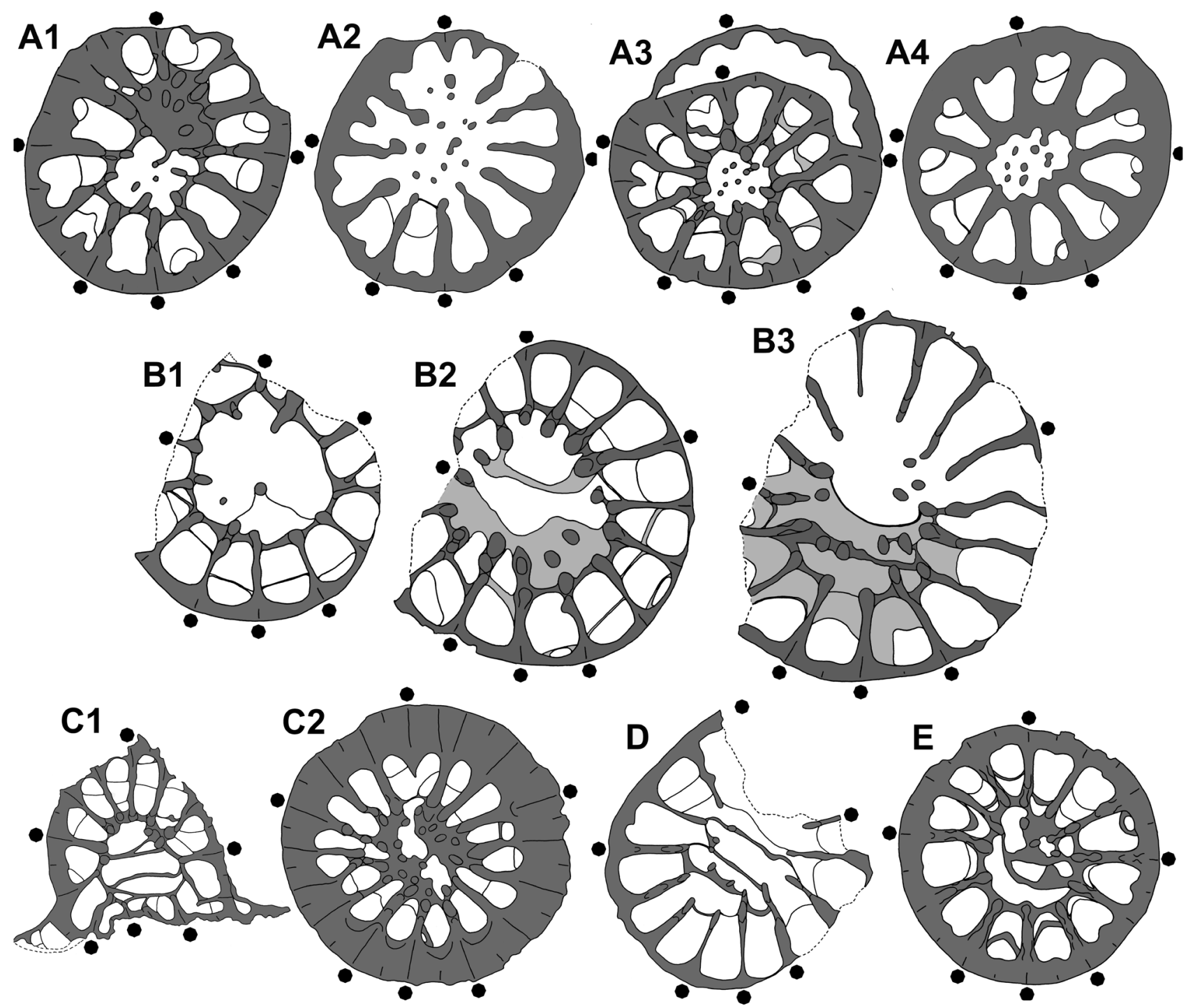

Figure 6. Spinaxon potyi sp. nov., paratypes, Thuringia and Montagne Noire. A1-4. MB.K.7949, former Geipel quarry in Schleiz, upper Vogelsberg Formation, bed 4A, Upper Frasnian, top of Upper Palmatolepis rhenana Zone, coll. D. Weyer 1995; subtabular cross sections (nos 9, 7, 6, 5), x10, in A2 with mature ampleximorph phase, in A3 with rejuvenescense (photos see Fig. 5 A1-3). B1-3. MB.K.7953, former Braunsberg quarry ESE Tegau, upper Vogelsberg Formation (loose block), Upper Frasnian, Lower-Upper Palmatolepis rhenana Zones, coll. D. Weyer 1966; subtabular cross sections (nos 6, 4, 2), x10 (photos see Fig. 5 C1-3). C1-2. MB.K.7960, Vogelsberg quarry NNE of Göschitz, upper Vogelsberg Formation, bed 2, Upper Frasnian, probably Lower Palmatolepis rhenana Zone, coll. D. Weyer 1983-1984; subtabular cross sections (nos 12, 4), x 7 (C1) and x6 (C2) (photos see Pl. 4 D1-3). D. MB.K.7952, former Kahlleite quarry SW of Rödersdorf, upper Vogelsberg Formation (loose block 14), Upper Frasnian, Lower or Upper Palmatolepis rhenana Zone, coll. D. Weyer 1985; subtabular cross section (no. 1), x6 (photos see P1. 4 B1-3). E. MB.K.7954, upper Coumiac quarry near Cessenon, bed 31b, Lower Palmatolepis linguiformis Zone, coll. R. Feist 1992; subtabular cross section (no. 4), x10 (photos see Pl. 4 A1-3).

7 B, Pl. 1 C1-2; MB.K.7964 = 5CS (TS), 2LS (TS) - bed AI Pl. 2 A1-4; MB.K.7965 = 2CS (TS), 2LS (TS) - bed $2-$ Fig. 7 C, Pl. 2 C1-3; MB.K.7966 = 5CS (TS) - bed 3 - Pl. 2 B1-5; Further specimens thin-sectioned, but not figured are numbered MB.K.7967-7986; specimens studied only with polished-etched surfaces bear the numbers MB.K.7987-7995 (with sub-numbers). Geipel quarry in Schleiz - two specimens: MB.K.7949 = 6CS (4P, 2TS), 3LS (1P, 2TS) - Fig. 5 A1-3, 6 A1-4; MB.K.7950 = 4CS (TS), 1R - Fig. 5 B1-4. Kahlleite quarry SW of Rödersdorf two specimens: MB.K.7951 = 5CS (TS) - Pl. 4 C1-3; MB.K.7952 $=6 \mathrm{CS}(\mathrm{TS}), 1 \mathrm{R}-$ Fig. 6 D, Pl. 4 B1-3. Braunsberg quarry ESE of Tegau - one specimen: MB.K.7953 = 6CS (TS) - Fig. 5 C1-3, 6 B1-3. Coumiac upper quarry near Cessenon - one specimen: MB.K.7954 $=6 \mathrm{CS}$, 1R (and 2CS of another attached Rugosa) - Fig. 6 E, Pl. 4 A1-3. Frasnian-Famennian stratotype section, bed $31 \mathrm{~b}$, Lower Palmatolepis linguiformis Zone, collected by Raimund Feist in 1992. The outcrop is described in Becker \& House (1994, p. 51, indicating the presence of solitary Rugosa corals in beds $31 \mathrm{c} 2$ and $31 \mathrm{e} 2$ ) and in House et al. (2000). One accompanying Rugosa in bed $31 \mathrm{~b}$ is Metriophyllum sp.; one further coral from bed 31 (without more detailed origin) is a Metrionaxon sp.
Diagnosis. Until the discovery of further species - identical with the actual diagnosis of the monotypic new genus.

Description. The small, long conical, mostly straight (excepting the talon curvature) or slightly cornute corals reach a length of $12-20 \mathrm{~mm}$ and a calicular diameter of $4-9 \mathrm{~mm}$. The larval phase started mostly with a horizontal talon fixed to any hard ground; often rejuvenescense occurred during later vertical growth. The smallest observed diameter was $2.5 \mathrm{~mm}$ (with already 22 septa and an aulos - Pl. 4 A1). Size of talon may amount to $6 \mathrm{~mm}$. The depth of calice is somewhat smaller than its diameter. The archaeotheca bears only growth rugae; longitudinal ribbing could not be seen. The cardinal septum of cornute coralla prefers the convex side (according to the talon position (Fig. 7 A2, P1. 1 G2, 4 A1) as in the ancestral genus Neaxon; an opposite orientation on the concave side is rare (Fig. $6 \mathrm{C} 1, \mathrm{Pl} .2 \mathrm{~B} 2$ ).

The adult septal apparatus comprises 28 septa; here a cardinal quadrant contains one or three less major septa than a counter quadrant (Fig. 7 A4, P1. 3 C2). Often, an earlier phase occurs with equal number of major septa in every quadrant (Fig. $6 \mathrm{~A} 2$, total 

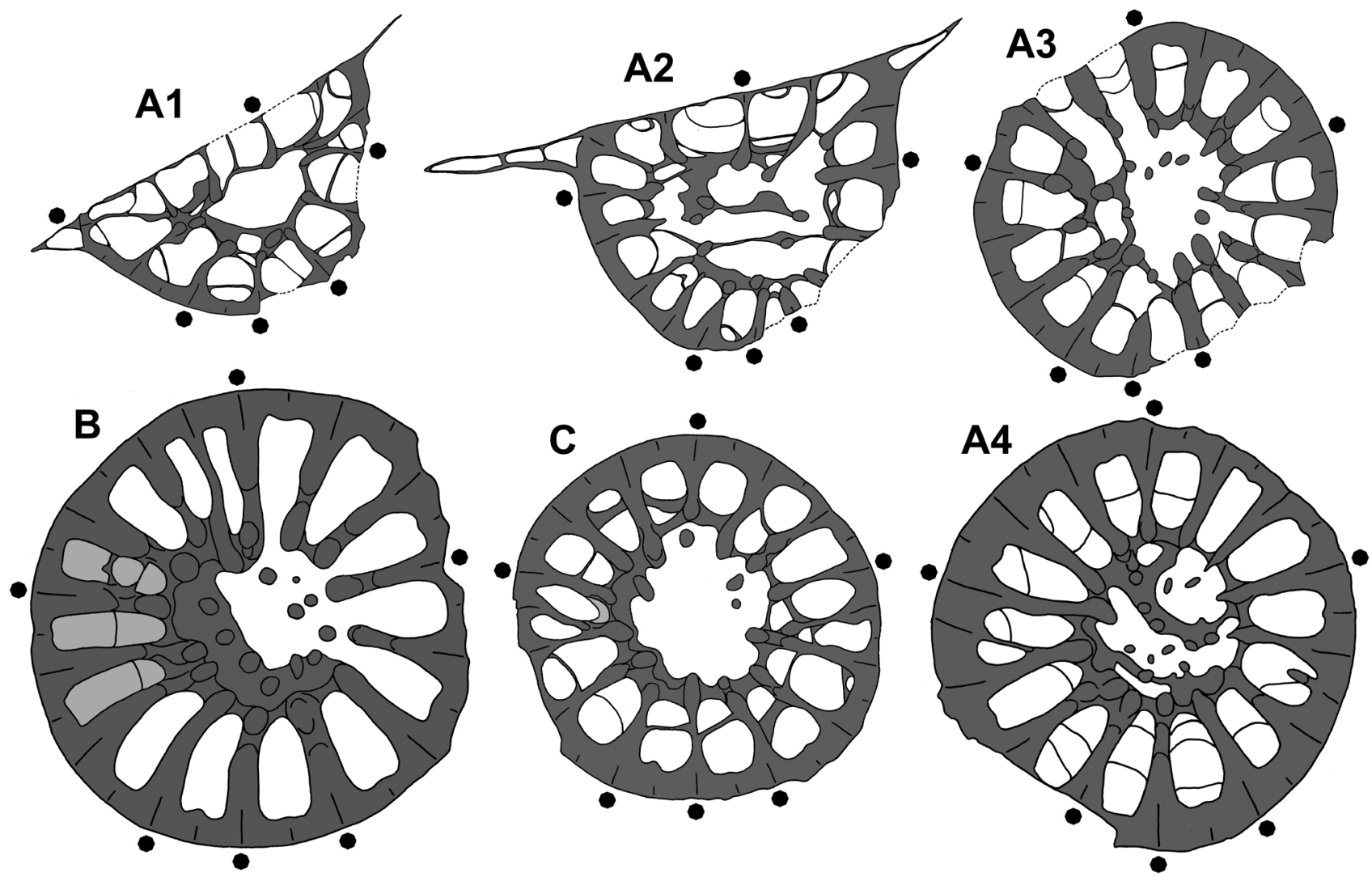

Figure 7. Spinaxon potyi sp. nov., holotype and paratype, Thuringia, Vogelsberg quarry NNE of Göschitz, upper Vogelsberg Formation, probably Lower Palmatolepis rhenana Zone, coll. D. Weyer 1983-1984. A1-4. MB.K.7957, holotype, bed A, subtabular cross sections (nos 8, 7, 6, 3), x10 (photos see P1. 1 G15). B. MB.K.7962, paratype, bed 2, cross section (no.2) at calicular base (subtabular regions in light grey), x10 (photos see Pl. 1 C1-2). C. MB.K.7965, paratype, bed 2, subtabular cross section (no. 6), x12 (photos see P1. 2 C1-3).

septal number 24). Specimens with a diameter $>6 \mathrm{~mm}$ (exception Fig. 6B) may construct 30 septa (Pl. 3 A7); the observed maximum is 34 septa ( $\mathrm{Pl} .3 \mathrm{D} 4)$. The youngest available stage (P1. 2 B1) still within the talon region has 20 septa. All the major septa - of course excepting the last one of every quadrant - are of equal length and unite in the lower calice to form an aulos. This circulotheca starts very early already in the talon phase and is formed as a separate interior wall by everted tangential wall pieces (with a dark median line) between the axial major septa ends - there is no basal dark line as in tabulae. The aulos is quite permanent and attains about one third of the corallum diameter in juvenile and middle growth stages, often enlarging in the mature stage to one half of the corallum diameter. There an ampleximorph trend is generally distributed, starting with local disappearance of interior wall pieces between several major septa (Fig. $5 \mathrm{C} 3$ ), and leading to a complete loss of any aulos structures (Fig. 6 D, Pl. 2 B5, C1). Occasionally, intersections of tabulae (with a basal dark line) can imitate local parts of an aulos wall during the ampleximorph phase. Sometimes (especially after rejuvenescense), the complete circulotheca may reappear (Figs 6 A1-4, 7 A3-4).

The septal microstructure is coarsely monacanth, besides a short phase of multitrabicular septal margins immediate at the upper calicular rim (P1. 3 A9) - as in the ancestral group around the genus Neaxon (Weyer, 1971, 1984a). The spiny margin of a major septum outside the aulos is clearly visible in P1. 1 G4. Fusion of the rather long trabiculae to form a platy septum occurs by comparatively thin stereoplasmatic deposits, causing typical undulated view of swelling up and down intersections in both transverse and longitudinal sections (Fig. 5 C1-3, P1. 2 C2). Due to missing recrystallizations, the original spiny structure is well visible (Pl. 4 D1-3). Within the circulotheca, the trabicular spines grow extremely long, remain totally unfused, and are bending up to a more and more nearly vertical orientation (P1. 2 C1, D1-2). They seem to suggest an axial structure (P1. $2 \mathrm{~A} 3)$, but there is no everted axial boss (Pl. $1 \mathrm{C} 2, \mathrm{G} 4)$. These exaggerated trabicular spines of the central region disappear during an ampleximorph phase (Pl. 2 B5, C1)

Minor septa are extremely short and of equal length (no preferred growth near the antiseptum). Their occasional "absence" within the calicular lumen (P1. 1 D2) is due to a transverse cut just between two trabicular spines. Many subtabular cross sections show no active minor septa: they have been reduced by continuous stereoplasmatic thickening of the archaeotheca during the calyx ontogenesis, but remain well visible now hidden within the wall. In cases of stronger recrystallization, such structures had been misinterpreted as a late ("zaphrentoidid") cyclic insertion of minor septa, which does not exist among Rugosa with their always serial ("cyathaxoniid" = retroserial) insertion mode.

Identification of six (or four) protosepta is not easy and requires an ontogenetic series of cross sections. They may offer phases at the four insertion points with major septa, not yet grown to full length and inclined towards (or even attached to) the neighbouring antiseptal major septum (P1. 2 B4, C3). The cardinal septum is never shortened, even in the higher calice (Pl. 1 D2, 3 A5-9). Apparent opposing pictures (Fig. 5 C1-3, 7 C, P1. 3 D3) represent incidental cuts just between two trabicular spines in a cross section.

A well developed convex tabularium consists of prevailing simple tabulae (and rare tabellae) in various inclination, from mostly sloping down to the wall at about $45^{\circ}$ to sometimes even horizontal (P1. 1 E2), outside the elevated circulotheca (P1. 3 C4-5). Inside the aulos, flat or slightly domed tabulae and also many tabellae are typical, often thickened by stereoplasma. The peripheral tabulae remain thin. There is no fossular structure. Criteria of a biform tabularium are absent: though sometimes tabulae intersections cross interseptal lumina not in tangential directions, but oblique (distance from the wall greater at the cardinal side of one lumen than at the antiseptal side, Fig. 6 B12) or without touching at the antiseptal side of one lumen (Fig. 6 A1, 4). Such structures are not regularly distributed over all the quadrants (Fig. 7 A4, C, with occasional opposite tabulae course). 
Variability. The rich available material allowed numerous illustrations in order to demonstrate the intraspecific variations. This is also needed for other small ahermatypic corals like Cyathaxonia Michelin, 1847, Laccophyllum Simpson, 1900, or Neaxon Kullmann, 1965, the species of which are often very similar and generally without clearly visible morphological differences.

Early ontogenesis demonstrates a common position of the cardinal septum at the convex side of the talon, a heritage from the ancestral genus Neaxon, but rarely an opposite position at the concave side was also observed. After the talon fixation on a hard object, the coral preferred a straight vertical growth; there are only few slightly cornute specimens, but no completely and regularly cornute coralla throughout their total length.

The comparison of the somewhat older rich collection (112 specimens) from the level below the Lower Kellwasser Event with the few (5 specimens, 3 of them illustrated) younger specimens from horizons below the Upper Kellwasser Event did not indicate specific differences. Only one common feature of the younger group, the slightly greater length of the subtabular mostly present minor septa (Figs $5 \mathrm{~A}, \mathrm{~B}, 6 \mathrm{~A}, \mathrm{E}$ ), might perhaps be of some significance, but this can not be judged on the basis of such restricted material.

The older population of the Vogelsberg quarry varies in the inclination of the peripheral tabulae - this can be observed in one and the same specimen (P1. 1 E1-2, 2 C1). The adult ampleximorph trend is missing, weakly indicated, or extremely developed. Its start is seen in specimens with major septa of still normal length, not longer united axially by a complete circulotheca, but ending free around the centre or connected only by tabulae (Fig. $5 \mathrm{C} 3$, 6 A2, D). Axial trabiculae found within the aulos of transverse sections are numerous (Fig. 6 A3-4, Pl. 1 A4, 2 D3) or few and situated only in the outer circle of the aulos (Fig. 6 B1-2, 7); this is partly related to the position of the section immediately upon a tabula or at different distances above a tabula.

\section{Occurrence. As for genus.}

\section{Acknowledgments}

Konrad Bartzsch (Saalfeld) always assisted during field work in Thuringia (1981-1983) and conodont sampling. Birgit Gaitzsch (Freiberg) improved our new section of 2014 by her sedimentological studies. Jean-Jacques Cornée and Catherine Girard (Montpellier) discussed during an excursion in 2015 the unique non-anoxic Kellwasser Event horizons of the Vogelsberg quarry. Gilbert Klapper (Iowa City) controlled determinations of Frasnian Palmatolepis species. Raimund Feist (Montpellier) donated his coral collection from the global stratotype of the Frasnian-Famennian boundary at Coumiac in 1995. Ilona Schäpan (Potsdam) provided the REM photos of conodonts. Ross McLean (Forresters Beach) and Tomasz Wrzołek (Sosnoviec) improved the first draft of the manuscript by their critical and linguistic reviews. My sincere thanks go to all of them for their kind help.

\section{References}

Ashouri, A.R., Abbasi, M.A. \& Khaksar, K., 2010. Alborziphyllinae, a new Late Devonian Rugose Corals subfamily. Journal of Sciences, Islamic Republic of Iran, 21 (2), 131-136.

Bartzsch, K., Blumenstengel, H., Gereke, M., Schindler, E., Weyer, D. \& Ziegler, W., 2001. Post-conference field trip (N, part 1): Thüringer Schiefergebirge (May 18-19, 2001), Field trips guidebook. In Jansen, E., Königshof, P., Plodowski, G. \& Schindler, E. (eds), $15^{\text {th }}$ International Senckenberg Conference, hosted by the Senckenbergische Naturforschende Gesellschaft, Frankfurt am Main May 11-21, 2001, Mid-Palaeozoic Bio- and Geodynamics, The North Gondwana-Laurussia Interaction, 87-113.

Bartzsch, K., Blumenstengel, H. \& Weyer, D., 1993. Field Excursion Saalfeld 31 July - 3 August 1993 to the Palaeozoic (Devonian) of Thuringia. Guidebook. Göttingen Meeting 31 July - 6 August 1993 (Gross Symposium), Subcommission on Devonian Stratigraphy SDS (International Union of Geological Sciences), IGCP Project 328: Palaeozoic Microvertebrates, 1-60.

Bartzsch, K., Blumenstengel, H. \& Weyer, D., 1999. Stratigraphie des
Oberdevons im Thüringischen Schiefergebirge. Teil 1: SchwarzburgAntiklinorium. Beiträge zur Geologie von Thüringen, Neue Folge, 6, 159-189.

Bartzsch, K., Blumenstengel, H. \& Weyer, D., 2008. Oberdevon des Thüringischen Schiefergebirges. In Weddige, K. (ed.), Deutsche Stratigraphische Kommission (ed.): Stratigraphie von Deutschland. VIII. Devon. Schriftenreihe der Deutschen Gesellschaft für Geowissenschaften, 52, 59-87.

Bartzsch, K. \& Weyer, D., 2012. Zur Stratigraphie des BreternitzMembers (Obere Clymenien-Schichten, Oberdevon) von Saalfeld (Schwarzburg-Antiklinorium, Thüringisches Schiefergebirge). Freiberger Forschungshefte, C 542, 1-54.

Becker, R.T., 1993. Stratigraphische Gliederung und AmmonoideenFaunen im Nehdenium (Oberdevon II) von Europa und Nord-Afrika. Courier Forschungsinstitut Senckenberg, 155, 1-405.

Becker, R.T. \& House, M.R., 1994. Kellwasser Events and goniatite successions in the Devonian of the Montagne Noire with comments on possible causations. Courier Forschungsinstitut Senckenberg, $169,45-77$

Berkowski, B., 2002. Famennian Rugosa and Heterocorallia from southern Poland. Palaeontologia Polonica, 61, 1-87.

Berkowski, B., 2004. Monospecific rugosan assemblage from the Emsian hydrothermal vents of Morocco. Acta Palaeontologica Polonica, 49 (1), 75-84.

Berkowski, B., 2006. Vent and mound rugose coral associations from the Middle Devonian of Hamar Laghdad (Anti-Atlas, Morocco). Geobios, 39 (2), 155-170.

Berkowski, B., 2008. Emsian deep-water Rugosa assemblages of Hamar Laghdad (Devonian, Anti-Atlas, Morocco). Palaeontographica, A 284 (1-3), 17-68.

Beushausen, L., 1900. Das Devon des nördlichen Oberharzes mit besonderer Berücksichtigung der Gegend zwischen Zellerfeld und Goslar. Abhandlungen der Königlich Preussischen Geologischen Landesanstalt, Neue Folge, 30, 1-383.

Bischoff, G., 1956. Oberdevonische Conodonten (toI $\delta$ ) aus dem Rheinischen Schiefergebirge. Notizblatt des Hessischen Landesamtes für Bodenforschung, 84, 115-137.

Bul'vanker, E.Z., 1958. Devonskie chetyrekhluchevye korally okrain Kuznetskogo basseyna. [Devonian tetracorals from the border of the Kuznezk basin]. Vsesoyuznyy Nauchno-Issledovatel'skiy Geologicheskiy Institut (VSEGEI); Leningrad. 1-212, atlas (93 pls.) [In Russian].

Cai, T-C., 1988. Tetracorals from Hebukehe Formation of northern Xinjiang. Acta Palaeontologica Sinica, 27 (1), 39-47. [In Chinese with an English summary].

Deubel, F., 1929. Erläuterungen zur Geologischen Karte von Preußen und benachbarten deutschen Ländern. Lieferung 301. Blatt Gräfenthal (2. Auflage), 1-139. Preussische Geologische Landesanstalt, Berlin.

Dybowski, W., 1873-1874. Monographie der Zoantharia sclerodermata rugosa aus der Silurformation Estlands, Nord-Livlands und der Insel Gotland, nebst einer Synopsis aller palaeozoischen Gattungen dieser Abtheilung und einer Synonymik der dazu gehörigen, bereits bekannten Arten. Archiv für die Naturkunde Liv-, Ehst- und Kurlands, Serie 1, 5 (3-4), 257-532.

Fedorowski, J., 2009. Morphogenesis and taxonomic value of the circumaxial skeleton in Rugosa (Anthozoa). Lethaia, 42 (2), 232-247.

Feist, R. \& Schindler, E., 1994. Trilobites during the Frasnian Kellwasser Crisis in European Late Devonian cephalopod limestones. Courier Forschungsinstitut Senckenberg, 169, 195-223.

Fomichev, V.D., 1953. Korally Rugosa i stratigrafiya sredne- i verkhnekamennougol'nykh i permskikh otlozheniy Donetskogo basseyna. [Rugosa corals from the Middle and Upper Carboniferous and from the Permian of the Donez basin]. Trudy, Vsesoyuznyy Nauchno-Issledovatel'skiy Geologicheskiy Institut (VSEGEI), Gosgeolizdat, Moskva, 1-622, atlas (p. 1-92, 44 pls.). [In Russian].

Frech, F., 1885. Die Korallenfauna des Oberdevons in Deutschland. Zeitschrift der Deutschen Geologischen Gesellschaft, 37 (1), 21-130.

Gereke, M., 2004. Das Profil Kahlleite Ost - die stratigraphische Entwicklung einer Tiefschwelle im Oberdevon des Bergaer Sattels (Thüringen). Geologica et Palaeontologica, 38, 1-31.

Gischler, E., 1992. Das devonische Atoll von Iberg und Winterberg im Harz nach Ende des Riffwachstums. Geologisches Jahrbuch, Reihe A, 129, 5-193.

Grabau, A.W., 1928. Palaeozoic corals of China. Part I. Tetraseptata II. Second contribution to our knowledge of the Streptelasmoid corals of China and adjacent territories. Palaeontologica Sinica, series B, $2(2) .1-175$ 
Guo, S.-Z, 1990. Frasnian-Famennian extinction and late Devonian rugose corals from Great Xing'an ranges, NE China. Acta Palaeontologica Sinica, 29 (4), 427-446. [In Chinese with an English summary].

Hill, D., 1939. Western Australian Devonian corals in the Wade Collection. Journal of the Royal Society of Western Australia, 25, 141-151.

Hill, D., 1954. Coral faunas from the Silurian of New South Wales and the Devonian of Western Australia. Bulletin, Bureau of Mineral Resources, Geology and Geophysics, 23, 1-51.

Hill, D., 1981. Rugosa and Tabulata. In Teichert, C. (ed.), Treatise on Invertebrate Paleontology, Part F, Coelenterata, Supplement 1. Geological Society of America \& University of Kansas Press, Lawrence, KS, 762 p.

Hill, D. \& Jell, J.S., 1971. Devonian corals from the Canning Basin, Western Australia. Bulletin, Geological Survey of Western Australia, 121, 1-158.

Holwill, F.J.W., 1964. The Coral genus Metriophyllum Edwards and Haime. Palaeontology, 7 (1), 108-123.

Holzapfel, E., 1882. Die Goniatiten-Kalke von Adorf in Waldeck. Palaeontographica, 28 (6), 225-261.

House, M.R., Becker, R.T., Feist, R., Flajs, G., Girard, C. \& Klapper, G., 2000. The Frasnian/Famennian boundary GSSP at Coumiac, Southern France. Courier Forschunsinstitut Senckenberg, 225, 59-75.

House, M. \& Ziegler, W., 1977. The goniatite and conodont sequences in the early Upper Devonian at Adorf, Germany. Geologica et Palaeontologica, 11, 69-108.

Ivaniya, V.A., 1965. Devonskie korally Rugosa Sayano-Altayskoy gornoy oblasti. [Devonian Rugosa corals from the Sayan-Altai mountain region]. Tomskiy Gosudarstvennyy Universitet, Izdatel'stvo Universiteta, Tomsk. 1-398. [In Russian].

Jia H.-Z., Xu S.-Y., Kuang G.-D., Zhang B.-F., Zuo Z.-B. \& Wu J.-S., 1977. [Anthozoa]. In Institute of Geological Sciences of Hubei, Geological Bureaus of Henan, Hubei, Hunan, Guangdong, Guanxi provinces (eds), Palaeontological Atlas of Central-South China. Part 2. Late Palaeozoic Volume. Geological Publishing House, Beijing, 109-270, 764-789. [In Chinese].

Koninck, L.G. de, 1872. Nouvelles recherches sur les animaux fossiles du terrain carbonifère de la Belgique. Première partie. Mémoires de 1'Académie Royale des Sciences, des Lettres et des Beaux-Arts de Belgique, 39, I-IV, 1-178.

Kullmann, J., 1965. Rugose Korallen der Cephalopodenfazies und ihre Verbreitung im Devon des südöstlichen Kantabrischen Gebirges (Nordspanien). Akademie der Wissenschaften und der Literatur in Mainz, Abhandlungen der mathematisch-naturwissenschaftliche Klasse, 1965 (2), 33-168.

Kullmann, J. \& Ziegler, W., 1970. Conodonten und Goniatiten von der Grenze Mittel- Oberdevon aus dem Profil am Martenberg (Ostrand des Rheinischen Schiefergebirges). Geologica et Palaeontologica, 4, 73-85.

Lang, W.D., 1923. Trends in British Carboniferous corals. Proceedings of the Geologists' Association, 34 (2), 120-136

Li V.D., 1979. Accurganaxon gen.nov. (Rugosa) iz nizhnego devona severo-vostochnoy Fergany. [Accurganaxon gen.nov. (Rugosa) from the Lower Devonian of the North-East Fergana]. Vestnik Leningradskogo Universiteta, 1979 (18), 107-109. [In Russian].

Liao W.-H. \& Cai T.-C., 1987. Sequence of Devonian rugose coral assemblages from northern Xinjiang. Acta Palaeontologica Sinica, 26 (6), 689-707. [In Chinese with an English summary].

Ludwig, R., 1865-1866. Corallen aus paläolithischen Formationen. Palaeontographica, 14 (4-6), 133-244, 249-252.

Matern, H., 1929. Die Ostracoden des Oberdevons. 1. Teil. Aparchitidae, Primitiidae, Zygobolbidae, Beyrichiidae, Kloedenellidae, Entomidae. Abhandlungen der Preussischen Geologischen Landesanstalt, Neue Folge, 118, 1-100

Matern, H., 1931. Das Oberdevon der Dill-Mulde. Abhandlungen der Preussischen Geologischen Landesanstalt, Neue Folge, 134, 1-139.

Michelin, H., 1841-1848. Iconographie zoophytologique, description par localités et terrains des polypiers fossiles de France et pays environnants. Librairie P. Bertrand, Paris, I-XII, 1-348, atlas (79 pls.) (dated 1840-1847)

Milne-Edwards, H. \& Haime, J., 1850-1855. A monograph of the British fossil corals. The Palaeontographical Society [Monographs], I-LXXXV, 1-322.

Müller, K.J., 1956. Cephalopodenfauna und Stratigraphie des Oberdevons von Schleiz und Zeulenroda in Thüringen. Beiheft zum Geologischen Jahrbuch, 20, 1-93.

Münster, G., 1832. Ueber die Planuliten und Goniatiten im UebergangsKalk des Fichtelgebirges. Bayreuth, F. C. Birner, 1-38.

Münster, G., 1839. Der Chiton priscus und einige andere seltene Versteinerungen aus der Uebergangs-Formation. Beiträge zur Petrefacten-Kunde, 1, 38-44.

Nicholson, H.A. \& Thomson, J. 1876. Descriptions of some new or imperfectly understood forms of Palaeozoic corals (Abstract). Proceedings of the Royal Society of Edinburgh, 9 (95), 149-150.
Opinion 946, International Commission of Zoological Nomenclature, 1971. Ludwig (R.), 1865-66, “Corallen aus paläolithischen Formationen" (Palaeontographica 14): suppressed under the plenary powers. Bulletin of Zoological Nomenclature, 27 (5-6), 226.

Opinion 2337. International Commission of Zoological Nomenclature, 2014. Species-group names proposed for Devonian ammonoids (Mollusca, Cephalopoda) by Sovbolew (1914a, 1914b) reinstated as available. Bulletin of Zoological Nomenclature, 71 (3), 184-188.

Paeckelmann, W., 1922. Oberdevon und Untercarbon der Gegend von Barmen. Jahrbuch der Preussischen Geologischen Landesanstalt, für 1920, 41 (2-1), 52-147.

Pfeiffer, H., 1954. Der Bohlen bei Saalfeld Thür. Geologie, Beiheft, 11, $1-105$.

Počta, P., 1902. Anthozoaires et Alcyonaires. In Barrande, J. (ed.), Système silurien du centre de la Bohême. Partie I. Recherches paléontologiques, Musée de Bohême, Praha, VIII.2. I-VIII, 1-347.

Richter, R. \& Richter, E., 1926. Die Trilobiten des Oberdevons. Abhandlungen der Preussischen Geologischen Landesanstalt, Neue Folge, 99, 1-314.

Roemer, F.A., 1866. Beiträge zur geologischen Kenntniss des Nordwestlichen Harzgebirges. V. Palaeontographica, 13, 201-236.

Różkowska, M., 1969. Famennian Tetracoralloid and Heterocoralloid fauna from the Holy Cross Mountains (Poland). Acta Palaeontologica Polonica, 14 (1), 1-187.

Sandberg, C.A., Ziegler, W., Dreesen, R. \& Butler, J.L. 1988. Late Frasnian mass extinction: conodont event stratigraphy, global changes, and possible causes. Courrier Forschungsinstitut Senckenberg, 102, 263-307.

Sandberger, G., 1853. Einige Beobachtungen über Clymenien; mit besonderer Rücksicht auf die westphälischen Arten. Verhandlungen des naturhistorischen Vereines der preussischen Rheinlande und Westphalens, 10, 171-216.

Sandberger, G., 1857. Paläontologische Kleinigkeiten aus den Rheinlanden. Einige noch unbeschriebene Versteinerungen vom Enkeberg bei Bredelar. Verhandlungen des naturhistorischen Vereines der preussischen Rheinlande und Westphalens, 14, 140-142.

Schindewolf, O.H., 1921. Versuch einer Paläogeographie des europäischen Oberdevonmeeres. Zeitschrift der Deutschen Geologischen Gesellschaft, 73 (1-3), 137-233.

Schindewolf, O.H., 1930. Aus der Stammesgeschichte der Korallen. Sitzungsberichte der Gesellschaft Naturforschender Freunde zu Berlin, 1930 (4-7), 118-132.

Schindewolf, O.H., 1931. On the genotype and septal development of the coral genus Petraia Münster. The Quarterly Journal of the Geological Society of London, 87 (4), 630-649.

Schindewolf, O.H., 1932. Über Polyparform und Septalapparat der Tetrakorallen. Centralblatt für Mineralogie, Geologie und Paläontologie, Abteilung B, 9, 464-478.

Schindewolf, O.H., 1942. Zur Kenntnis der Polycoelien und Plerophyllen. Eine Studie über den Bau der "Tetrakorallen" und ihre Beziehungen $\mathrm{zu}$ den Madreporarien. Abhandlungen des Reichsamts für Bodenforschung, Neue Folge, 204, 1-324.

Schindler, E., 1990. Die Kellwasser-Krise (hohe Frasne-Stufe, OberDevon). Göttinger Arbeiten zur Geologie und Paläontologie, 46, 1-115.

Schmidt, H., 1921. Das Oberdevon-Culm-Gebiet von Warstein I.W. und Belecke. Jahrbuch der Preussischen Geologischen Landesanstalt, for 1920, 41 (1), 254-339.

Schouppé, A. v. \& Stacul, P., 1959. Säulchenlose Pterocorallia aus dem Perm von Indonesisch-Timor (mit Ausnahme der Polycoeliidae). Eine morphogenetische und taxonomische Untersuchung. In Wanner, J. (ed.), Beiträge zur Geologie von Niederländisch-Indien. Palaeontographica, Supplement-Band, 4 (5), 197-359.

Schriel, W., 1954. Die Geologie des Harzes. Niedersächsisches Amt für Landesplanung und Statistik, Veröffentlichungen, Reihe A, 49 (Schriften der Wirtschaftswissenschaftlichen Gesellschaft zum Studium Niedersachsens E.V., Neue Folge, 49, I-XIV, 1-308.

Simpson, G.B., 1900. Preliminary descriptions of new genera of Paleozoic rugose corals. Bulletin of the New York State Museum, 8 (39), 199-222.

Smith, S., 1945. Upper Devonian Corals of the Mackenzie River Region, Canada. Special Papers, Geological Society of America, 59, 1-126.

Sobolew, D.N., 1914a. Nabroski po filogenii goniatitov' [Outlines of the phylogeny of goniatites]. Izvestiya Varshavskago Politekhnicheskago Instituta, 1914 (1), 1-193. [In Russian].

Sobolew, D.N., 1914b. Über Clymenien und Goniatiten. Paläontologische Zeitschrift, 1, 348-378.

Sorauf, J.E., 1992. Late Devonian (Famennian) rugose coral fauna of the Percha Shale of Southwestern New Mexico. Journal of Paleontology, 66 (5), 730-749.

Sorauf, J.E. \& Pedder, A.E.H., 1986. Late Devonian rugose corals and the Frasnian-Famennian crisis. Canadian Journal of Earth Sciences, 23 (9), 1265-1287.

Soshkina, E.D., 1939. Verkhnedevonskie korally Rugosa Urala. [Upper Devonian corals Rugosa of the Ural]. Trudy Paleontologicheskogo Instituta, Akademiya Nauk SSSR, 9 (2), 1-88. [In Russian]. 
Soshkina, E.D., 1941. Sistematika srednedevonskikh Rugosa Urala. [Systematics of the Middle Devonian Rugosa of the Urals]. Trudy Paleontologicheskogo Instituta, Akademiya Nauk SSSR, 10 (4), 1-54. [In Russian].

Soshkina, E.D., 1952. Opredelitel' devonskikh chetyrekhluchevykh korallov. [Determination book of Devonian tetracorals]. Trudy Paleontologicheskogo Instituta, Akademiya Nauk SSSR, 39, 1-127. [In Russian].

Soshkina, E.D., 1960. Turneyskie korally Rugosa i ikh vzaimootnosheniya s devonskimi. [Tournaisian Rugosa and their relations to Devonian corals]. In Varsanofeva, V.A. (ed.), Sbornik trudov po geologii paleontologii. Akademiya Nauk SSSR, Komi Filial, 272-329. [In Russian].

Spasskiy, N.Y., 1977. Devonskie rugozy SSSR (sistematika, stratigraficheskoe i geograficheskoe znachenie). [Devonian Rugosa of the USSR (systematics, stratigraphical and geographical importance]. Ministerstvo Vysshevo i Srednego Spetsial'nogo Obrazovaniya RSFSR, Izdatel'stvo Universiteta, Leningrad, 1-285. [In Russian].

Stainbrook, M.A., 1946. Corals of the Independence Shale of Iowa. Journal of Paleontology, 20 (5), 401-427.

Stauffer, C. R., 1938. Conodonts of the Olentangy Shale. Journal of Paleontology, 12, 411-443.

Verrill, A.E., 1865. Classification of polyps (Extract condensed from a Synopsis of the Polypi of the North Pacific Exploring Expedition, under Captains Ringgold and Rodgers, U.S.N.). [Part I]. Proceedings of the Essex Institute, Communications read before the Essex Institute, 1864-1865, 4, 145-152.

Volk, M., 1939. Das Oberdevon am Schwarzburger Sattel zwischen Südrandspalte und Kamm des Thüringer Waldes. Sitzungsberichte der physikalisch-medizinischen Sozietät, 70, 147-278.

Wedekind, R., 1913. Die Goniatitenkalke des unteren Oberdevon von Martenberg bei Adorf. Sitzungsberichte der Gesellschaft naturforschender Freunde, 1, 23-77.

Wedekind, R., 1918. Die Genera der Palaeoammonoidea (Goniatiten) (mit Ausschluß der Mimoceratidae, Glyphioceratidae und Prolecanitidae). Palaeontographica, 62, 85-184.

Weissermel, W., 1939. Die Korallen des thüringischen Devons. 1. Korallen aus Oberdevon im westlichen Schiefergebirge Thüringens. Jahrbuch der Preussischen Geologischen Landesanstalt, 59, 353-369.

Weissermel, W., 1943. Korallen aus meist kalkigem Oberdevon OstThüringens (Korallen aus dem thüringischen Devon III. Teil). Zeitschrift der Deutschen Geologischen Gesellschaft, 95 (1-2), 1-12.

Weyer, D., 1970. The Middle Tournaisian rugose coral Zaphrentis delepini Vaughan 1915. Bulletin de la Société Belge de Géologie, de Paléontologie et d'Hydrologie, 79 (1), 55-83.

Weyer, D., 1971. Neaxon regulus (Rh. Richter, 1848), ein Leitfossil der mitteleuropäischen Wocklumeria-Stufe (Anthozoa, Rugosa; Oberdevon). Geologie, 20 (3), 292-315.

Weyer, D., 1977. Revision des Genus Schindewolfia Weissermel, 1943 (Anthozoa, Rugosa; Unterdevon, Harz). Zeitschrift für Geologische Wissenschaften, 5 (3), 305-319.

Weyer, D., 1978. Zwei neue Rugosa-Genera aus dem marokkanischen und thüringischen Devon. Jahrbuch für Geologie (Zentrales Geologisches Institut Berlin), 74 (9-10), 289-345.

Weyer, D., 1980. Das silurisch-devonische Rugosa-Genus Petraia Münster 1839. Freiberger Forschungshefte, C, 357, 25-41.

Weyer, D., 1981. Bathyale Rugosa (Anthozoa) aus pelagischem Oberems (Unterdevon) im Thüringischen Schiefergebirge. Abhandlungen und Berichte für Naturkunde und Vorgeschichte (Kulturhistorisches Museum Magdeburg), 12 (3), 23-73.

Weyer, D., 1984a. Neaxon cheilos n.sp. aus dem Unterfamenne von Schleiz im Thüringer Schiefergebirge (Anthozoa, Rugosa; Oberdevon). Abhandlungen und Berichte für Naturkunde und Vorgeschichte (Kulturhistorisches Museum Magdeburg), 12 (5), 3-16, 77-83.

Weyer, D., 1984b. Schindewolfia Weissermel 1943 (Anthozoa, Rugosa) im Unterdevon von Bithynien. Abhandlungen und Berichte für Naturkunde und Vorgeschichte (Kulturhistorisches Museum Magdeburg), 12 (5), 17-28, 84-85.

Weyer, D., 1984c. Korallen im Paläozoikum von Thüringen. Hallesches Jahrbuch für Geowissenschaften, 9, 5-33.

Weyer, D., 1991. Pseudopetraia Soshkina 1951 (Anthozoa, Rugosa) aus dem Unterdevon des Thüringischen Schiefergebirges. Abhandlungen und Berichte für Naturkunde und Vorgeschichte (Kulturhistorisches Museum Magdeburg), 15, 9-24.

Weyer, D., 1996. Nichlavalla sytovae n.g. n.sp. aus dem Lochkovian von Podolien (Anthozoa, Rugosa; Unterdevon, Ukraine). Abhandlungen und Berichte für Naturkunde (Museum für Naturkunde Magdeburg), [for 1995], 19: 83-103.

Weyer, D., 2000. Revision der Gattung Czarnockia Różkowska 1969 (Anthozoa, Rugosa; Oberdevon). Abhandlungen und Berichte für Naturkunde (Museum für Naturkunde Magdeburg), 21, 75-107.
Weyer, D., 2001. Muenstraia, ein neues Rugosa-Genus (Anthozoa) aus dem Obersilur und Unterdevon. Mitteilungen aus dem Museum für Naturkunde in Berlin, Geowissenschaftliche Reihe, 4, 71-82.

Weyer, D., 2004. Neue Rugosa-Funde aus dem Unter-Famenne von Deutschland (Anthozoa, Oberdevon). Geologisches Jahrbuch Hessen, 131, 203-223.

Weyer, D., Feist, R. \& Girard, C., 2003. Conodonta, Trilobita, and Anthozoa near the Late Frasnian Upper Kellwasser Event of the Geipel Quarry section in Schleiz, Thuringian Mountains (Germany). Mitteilungen aus dem Museum für Naturkunde in Berlin, Geowissenschaftliche Reihe, 6, 71-78.

Weyer, D. \& Zagora, K., 1990. Die ehemalige Givet-Fossilfundstelle Büchenberg im Unterharz. Hallesches Jahrbuch für Geowissenschaften, 15, 21-42.

Wu W.-S. \& Liao W.-H., 1988. Some Famennian rugose corals from Yishan, Guangxi. Acta Palaeontologica Sinica, 27 (3), 269-277. [In Chinese with an English summary].

Yü C.-M., 1957. On the occurrence of a new rugose coral from the Middle Ordovician of Sinkiang province, N.W. China. Acta Palaeontologica Sinica, 5 (2), 307-324. [In Chinese with an English summary].

Zagora, K. \& Aehnelt, M., 2009. Oberdevon in NE-Deutschland Ergebnisse von 15 Tiefbohrungen im Küstengebiet von Vorpommern. Zeitschrift für Geologische Wissenschaften, 37 (3), 153-205.

Ziegler, W. \& Sandberg, C.A., 1990. The Late Devonian standard conodont zonation. Courier Forschungsinstitut Senckenberg, 121, $1-115$.

Zimmermann, E., 1915. Erläuterungen zur Geologischen Karte von Preußen und benachbarten Bundesstaaten. Lieferung 181. Blatt Schleiz, 1-97, Königlich Preußische Geologische Landesanstalt.
Manuscript received 23.09.2015, accepted in revised form 01.12.2015, available on line 07.04.2016 

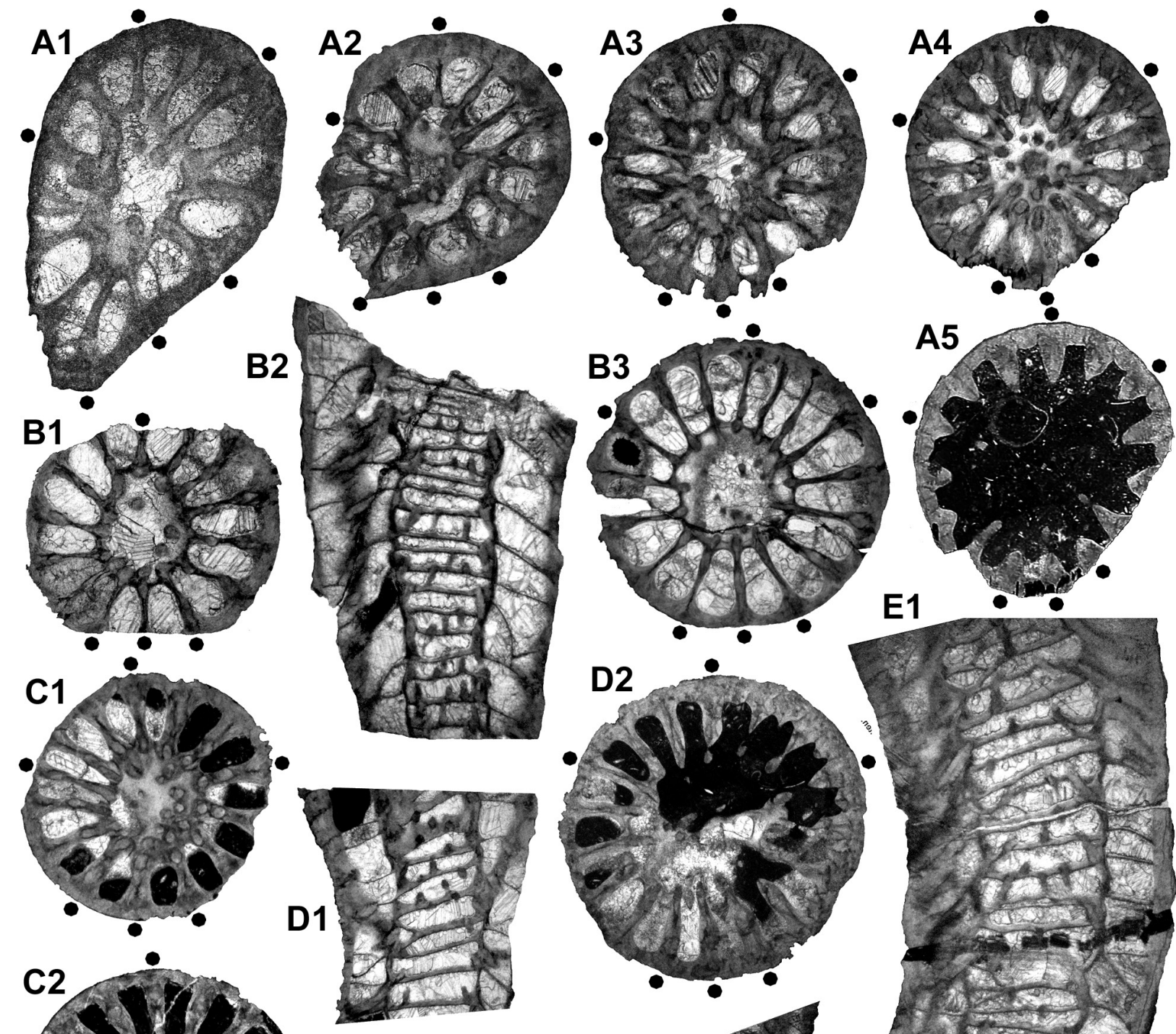

B3
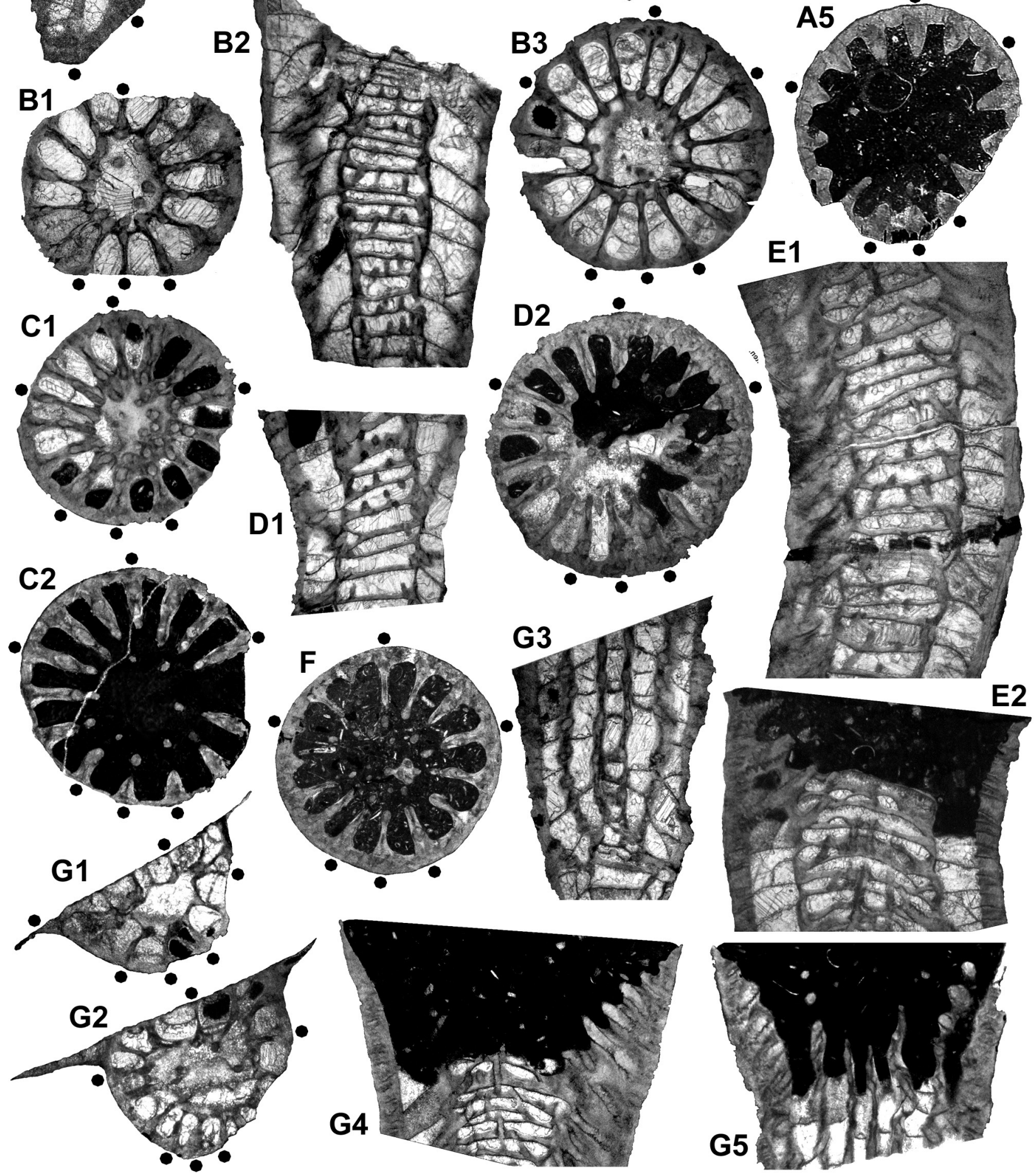

Plate 1. Spinaxon potyi sp. nov., holotype and paratypes, Vogelsberg quarry NNE of Göschitz, upper Vogelsberg Formation, Upper Frasnian, probably Lower Palmatolepis rhenana Zone, coll. D. Weyer 1983-1984. A1-5. MB.K.7956, bed A, series of cross sections (nos 11, 10, 9, 7 = subtabular,3 = calicular), x12 (A1), x10 (A2), x8 (A3), and x6 (A4, A5) (drawings see P1. 3 1-9). B1-3. MB.K.7955, bed B, subtabular sections, x10 (B1), x8 (B2), and x7 (B3). C1-2. MB.K.7963, bed 2, subtabular (C1) and calicular (C2) cross section, x7 (drawing see Fig. 7 B). D1-2. MB.K.7961, bed B, sections (nos 9, 5) near the calicular base, $x 6$ (drawing see Pl. 3 D1-4). E1-2. MB.K.7962, bed 3, median (E1) and slightly eccentric (E2) longitudinal sections (nos 8, 6), x8 (drawings see Pl. 3 C1-5). F. MB.K.7959, bed 3, cross section (no. 2) in the lower calice, x6 (drawings see Pl.3 B1-3). G1-5. MB.K.7957, holotype, bed A, early cross sections (nos 8, 7), $\mathrm{x} 8$, and longitudinal sections (nos 5, 2, 1), strongly eccentric outside the circulotheca (G3, G5) and slightly eccentric inside the aulos (G4), x8 (G3) and x7 (G4, G5) (drawings see Fig. 7 A1-4). 


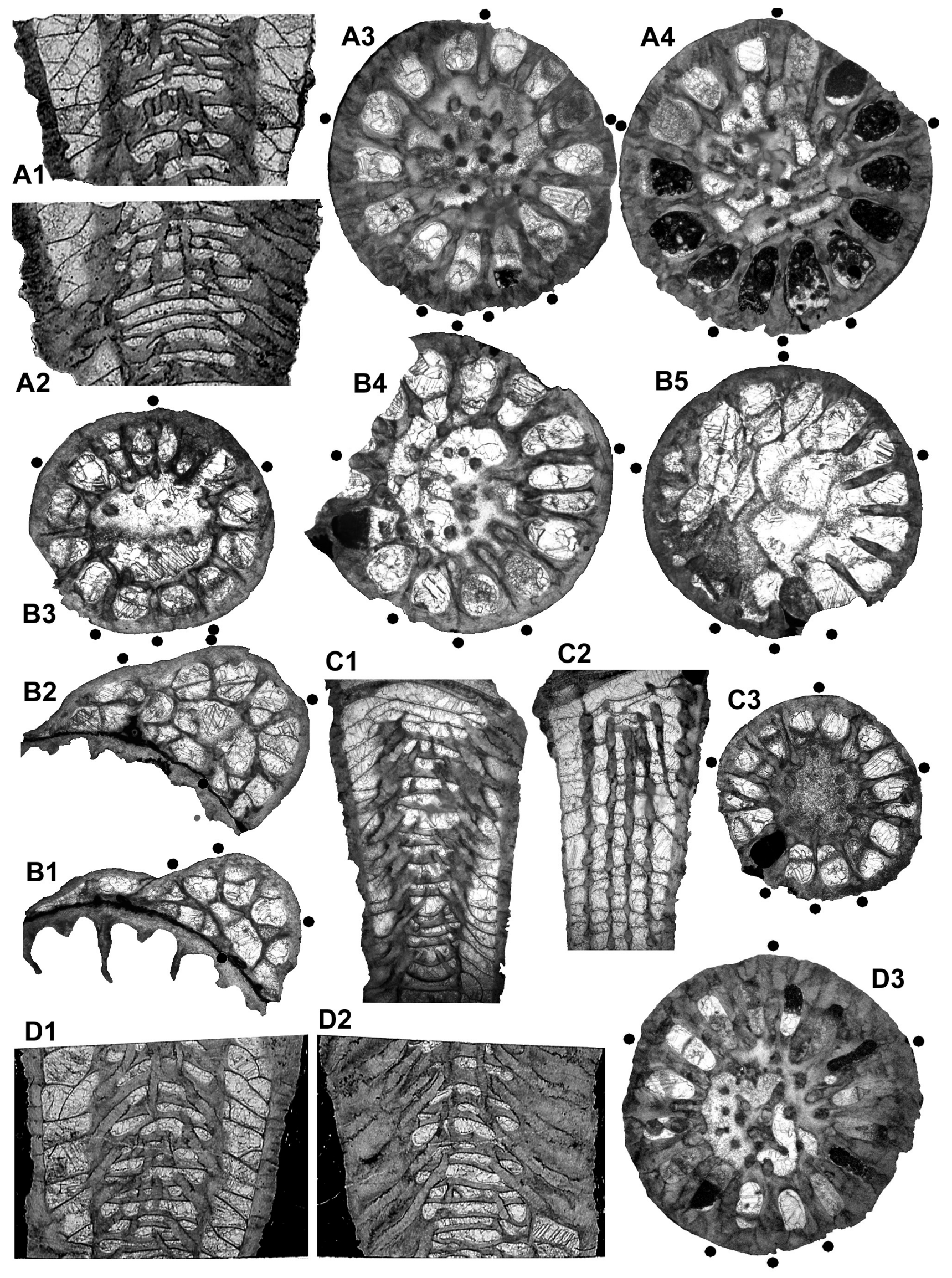

Plate 2. Spinaxon potyi sp. nov., paratypes, Vogelsberg quarry NNE of Göschitz, upper Vogelsberg Formation, Upper Frasnian, probably Lower Palmatolepis rhenana Zone, coll. D. Weyer 1983-1984. A1-4. MB.K.7964, bed AI, slightly eccentric subtabular median longitudinal sections (no. 3a, 3b), x10, and cross sections (nos 4, 5), x8. B1-5. MB.K.7966, bed 3, subtabular cross sections, x10 (B1-4) and x8 (B5, extreme ampleximorph). C1-3. MB.K.7965, bed 2, median and eccentric (outside the aulos) longitudinal section, x6, and basal cross section, x10 (drawing see Fig. 7 C). D1-3. MB.K.7958, bed 1, slightly eccentric and median longitudinal section (nos 6,7), x7, and cross section (no. 4), x7. 

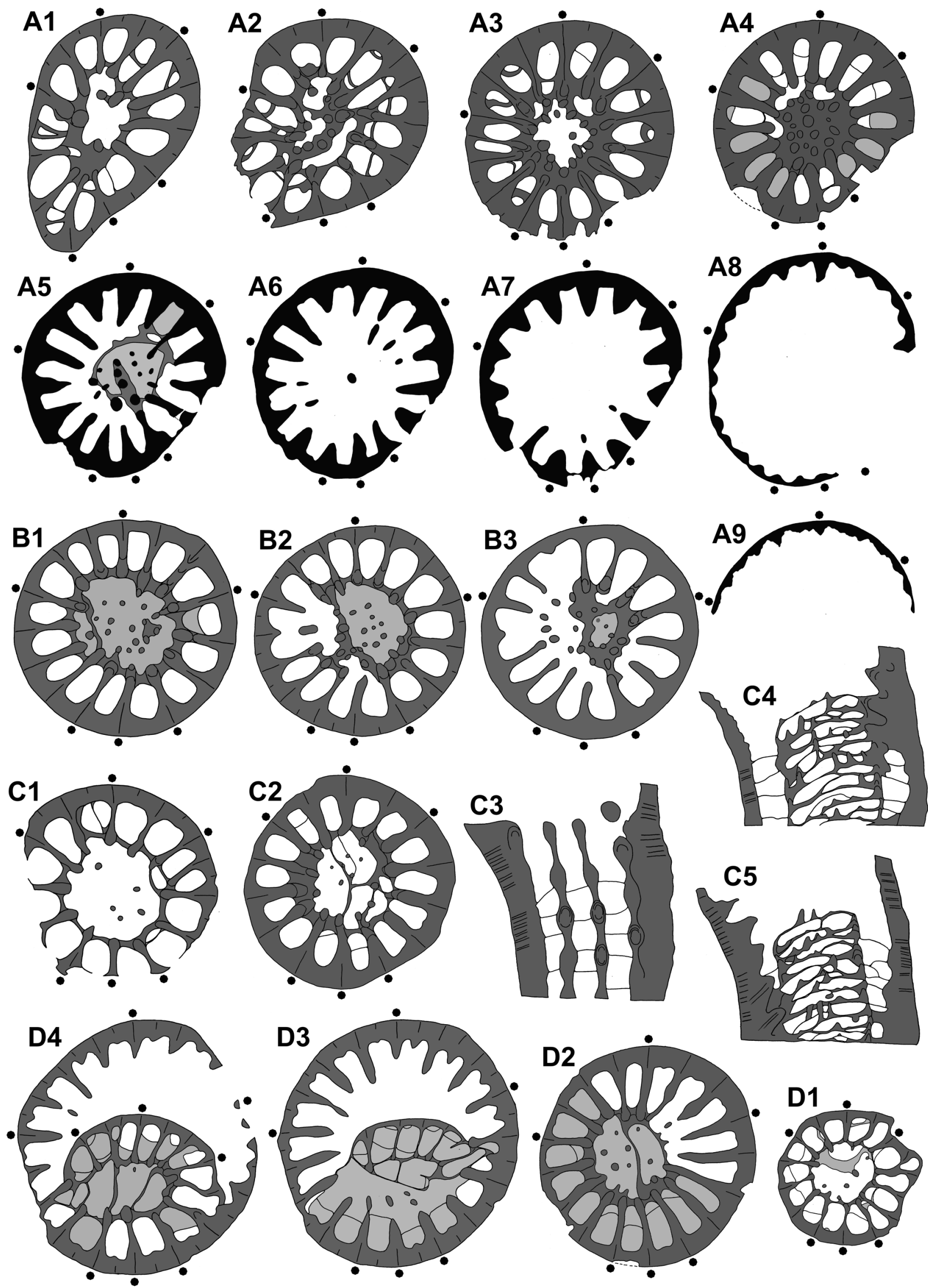

Plate 3. Spinaxon potyi sp. nov., paratypes, Vogelsberg quarry NNE of Göschitz, upper Vogelsberg Formation, Upper Frasnian, probably Lower Palmatolepis rhenana Zone, coll. D. Weyer 1983-1984. A1-9. MB.K.7956, bed A, series of subtabular and calicular cross sections (light grey lumina = calicular in A4, subtabular in A5), x10 (A1-2), x8 (A3), and x6 (A4-9) (photos see P1. 1 A1-5). B1-3. MB.K.7959, bed 3, cross sections near base of calice (nos 5, 4, 3; lumina calicular at periphery, subtabular within circulotheca), x7 (B1) and x6,5 (B2-3) (photo see P1. 1 F). C1-5. MB.K.7962, bed 3, subtabular cross sections (nos 9, 7), $\mathrm{x} 10(\mathrm{C} 1)$ and $\mathrm{x} 7(\mathrm{C} 2)$, longitudinal sections with base of calice ( $\mathrm{C} 3$ tangential outside aulos, $\mathrm{x} 7$; $\mathrm{C} 4$ slightly eccentric and $\mathrm{C} 5$ median within circulotheca, x6) (photos see P1. 1 E1-2). D1-4. MB.K.7961, bed B, subtabular and basal calicular cross sections with rejuvenescense (nos 10, 6, 4, 3, light grey lumina = subtabular), x6 (photos see Pl. 1 D1-2). 

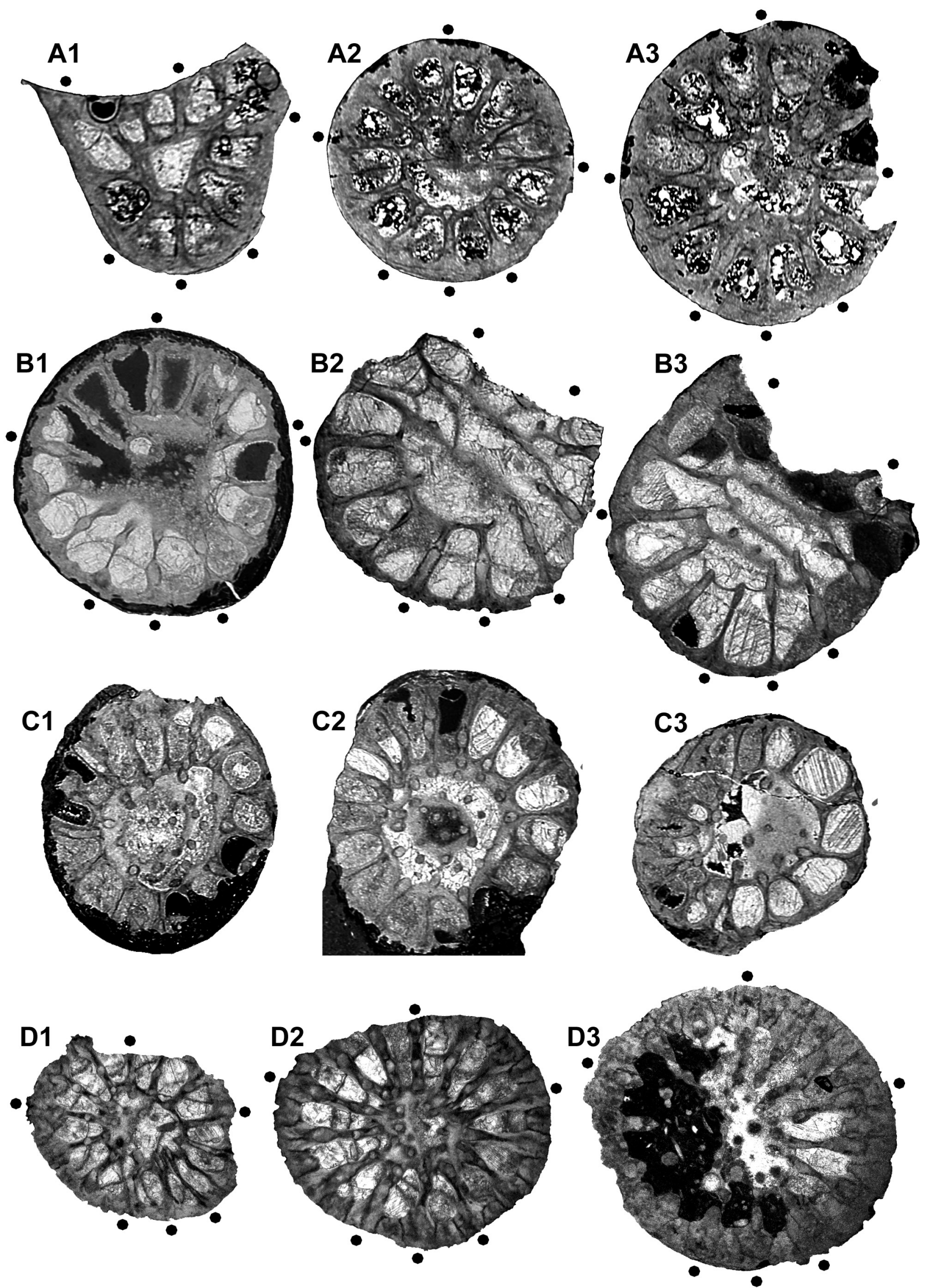

Plate 4. Spinaxon potyi sp. nov., paratypes, Thuringia and Montagne Noire. A1-3. MB.K.7954, upper Coumiac quarry near Cessenon, bed 31b, Lower Palmatolepis linguiformis Zone, coll. R. Feist 1992; subtabular and calicular cross sections (nos 6, 4, 3), x15 (A1) and x12 (A2-3) (drawing see Fig. 64 ). B1-3. MB.K.7952, former Kahlleite quarry SW of Rödersdorf, upper Vogelsberg Formation (loose block 14), Upper Frasnian, Lower or Upper Palmatolepis rhenana Zone, coll. D. Weyer 1985; subtabular cross sections (nos 5, 2, 1), x10 (B1-2) and x9 (B3) (drawing see Fig. 6 D). C1-3. MB.K.7951, former Kahlleite quarry SW of Rödersdorf, upper Vogelsberg Formation (loose block 13), Upper Frasnian, Upper Palmatolepis rhenana Zone, coll. D. Weyer 1985; subtabular cross sections (nos 5, 4, 2), x10 (identification of protosepta impossible). D1-3. MB.K.7960, Vogelsberg quarry NNE of Göschitz, upper Vogelsberg Formation, Upper Frasnian, probably Lower Palmatolepis rhenana Zone, coll. D. Weyer 1983-1984, subtabular and basal calicular cross sections, x8 (drawings see Fig. 6 C1-2). 